Portland State University

PDXScholar

$1-1-2009$

\title{
Dutch Spatial Planning: The Coordination of Compact Development and Affordable Housing
}

Andrew James Eickmann

Portland State University

Follow this and additional works at: https://pdxscholar.library.pdx.edu/open_access_etds Let us know how access to this document benefits you.

Recommended Citation

Eickmann, Andrew James, "Dutch Spatial Planning: The Coordination of Compact Development and Affordable Housing" (2009). Dissertations and Theses. Paper 360.

https://doi.org/10.15760/etd.360

This Thesis is brought to you for free and open access. It has been accepted for inclusion in Dissertations and Theses by an authorized administrator of PDXScholar. Please contact us if we can make this document more accessible: pdxscholar@pdx.edu. 
Dutch Spatial Planning:

The Coordination of Compact Development

and Affordable Housing

\section{by}

Andrew James Eickmann

A thesis submitted in partial fulfillment of the requirements for the degree of

Master of Urban Studies

Committee Members:

Sy Adler, Chair

Carl Abbott

Loren Lutzenhiser

Portland State University

2009 


\begin{abstract}
This case study combines elements of exploration and description to examine the interaction of growth management and housing affordability within the Dutch system of spatial planning. In Section I, I introduce the research framework and pose the central research question: How do planners and policymakers in the Netherlands conceptualize and manage the relationship between land and housing markets, and the effects of that relationship on housing affordability? In Section II, I provide an overview of Dutch spatial planning, focusing on planning and policymaking at the national and municipal levels, and summarizing the postwar-era "bundled deconcentration" approach to growth management. Section III covers the economic and political shifts of the 1980s and early 1990s, a period that marked the end of "bundled deconcentration" and ushered in the "compact city" approach to spatial planning. In Section IV, I introduce contemporary issues of land scarcity and housing supply stagnation and summarize my primary interview findings. In Section V, I elaborate on my interview findings and discuss the broader perspectives offered by Dutch planners and economists. Finally, in Section VI, I conclude the case study with a review of findings, final reflections, and suggestions for future research.
\end{abstract}




\section{TABLE OF CONTENTS}

ABSTRACT _

LIST OF FIGURES _ iv

SECTION I: RESEARCH SETUP

Managing Growth in the Netherlands

Regulatory Growth Management and Housing Prices __ 3

Land and Housing Markets __ 6

Growth Management in International Settings ___ 8

Problem Framework _ 9

Statement of Purpose_ 10

Unit of Analysis _ 11

Central Research Question __ 12

Methodology _ 12

Research Question Framework _ 13

Method of Investigation 15

SECTION II: GROWTH MANAGEMENT IN THE POST-WAR PERIOD__ 16

Scope and Intergovernmental Structure of Dutch Spatial Planning __ 16

The Role of National Planning ___ 19

The Role of Municipal Planning _ 21

Building Permits and "Postage Stamp Planning"__ 21

Supplying Buildable Land___ 23

Growth Management and the Combination of Positive and Negative Planning _ 25

Preserving the Green Heart__ 27

Structuring Urbanized Areas _ 29

The 'Marriage of Convenience' and the Housing Imperative __ 31

Section II Summary__ 36

Reflections on the Problem Framework 35

SECTION III: GROWTH MANAGEMENT IN THE 1980s AND 1990s _ 38

The Recession of the 1980's _ 38

The VINEX Era___ 39

Continued Privatization___ 42

From Steering Growth to Limiting Land Supply __ 43

The Great Miscalculation _ 45

Section III Summary _ 47

SECTION IV: INTERVIEW FINDINGS _ 48

Assessing Growth Management in the VINEX Era __ 48

A Scarcity of Buildable Land _ 51

Stagnant Housing Production

Causes of Housing Stagnation _ 55

Land Availability ___ 56

Red Tape and Development Delays___ 60

Organized Scarcity _ 62 
Density of Development

The State of Low-Income Housing

The Gap in the Middle

Findings Summary

SECTION V: DISCUSSION OF FINDINGS _ 76

Broad Support for Growth Management__ 76

The Planning Perspective

An Alternative Economic Perspective _ 79

Applications to the Research Subject __ 84

Policy Implications _ 87

SECTION VI: CONCLUSION _ 91

Research Summary __ 91

Reflections and Suggestions for Future Research___ 94

WORKS CITED___ 99

APPENDIX A: BENGSTON, ET AL (2004) GROWTH

MANAGEMENT TYPOLOGY

APPENDIX B: BASIC TOPOGRAPHY AND LAND USE OF

THE NETHERLANDS

APPENDIX C: EXAMPLE INTERVIEW SCRIPT __ 107

APPENDIX D: LIST OF INTERVIEW SUBJECTS AND DATES___ 110

APPENDIX E: MAP OF THE RANDSTAD 


\section{LIST OF FIGURES}

FIGURE 1: Layers of Government and their Areas of

Planning Responsibility

FIGURE 2: The Green Heart

FIGURE 3: Relative Incidences, Areas and Population Densities of District Types

FIGURE 4: Housing Price and Production, 1965-2002 


\section{SECTION I: RESEARCH SETUP}

\section{Managing Growth in the Netherlands}

Although the term has only recently been adopted in Dutch planning literature, the people of the Netherlands have arguably been practicing a basic form of growth management for many centuries. Since the earliest human settlements of the modernday Netherlands, residents of this marshy, low-lying territory have been engaged in a collective project to maximize the utility of their land. Much of the country's current land base-including the entire Randstad conurbation, where the bulk of the national population resides_-lies below sea level, and was rendered habitable only through a sustained campaign of battles against encroaching waters. ${ }^{1}$ Communities dug ditches to drain marshlands, built windmills to pump the ditches, and eventually constructed a national network of canals for the purpose of water management. The product of this grand collective effort—-dry land—is the nation's most precious natural resource (Needham 2007, 21-28).

Land use planners-or spatial planners, as they are known in the Netherlands — are the modern stewards of the nation's limited land supply. Building on a long Dutch tradition of dense settlement, planners have worked since the midtwentieth century to preserve agricultural land and to promote compact urban forms in the face of rapid national population growth. Modern spatial planning in the Netherlands is coordinated through an elaborate and muscular system of public agencies operating at the national, provincial, municipal, and local levels.

As a result of these historic traditions and modern-day planning efforts, 
urbanized areas in the Netherlands are among the most densely populated on Earth (Needham 2007, 25). In the year 2000, the Netherlands was home to 16 million inhabitants residing in a built-up area of 4,799 square kilometers - or just $14.5 \%$ of the nation's dry land supply. 22,260 square kilometers - or $69 \%$ of the nation's land base - remained in agricultural use, and 4,835 square kilometers (14.5\% of dry land) were forested or natural areas (Needham 2007, 22).

The wise use of land has historically been a top priority of spatial planning in the Netherlands. However, modern Dutch planners and policymakers have also displayed a commitment to principles of tolerance, inclusion, and social justice. In 1901, in an effort to improve living standards in blighted urban areas, the Netherlands adopted Europe's first policy of urban renewal (i.e. the Housing Act of 1901). After the Second World War, principles of tolerance and social inclusion gained new status in the Netherlands as the foundations of a just society. These principles were quickly incorporated into the institutions and policies that shaped Dutch cities during an era of booming postwar urbanization. With massive financial support from the central government, social housing associations in the Netherlands became the largest and strongest in Europe, building and maintaining upwards of 50\% of the nation's new urban housing stock and securing a place for low- and middle-income residents in the cultural and economic centers of Dutch life. The integration of social housing efforts with national spatial planning is the subject of Section II.

In light of these efforts to protect open space and promote equitable urban development, the Netherlands has been recognized as a leader in the field of European 
growth management (Evers et al 2000; van der Valk 2002). Writing in the mid-1990s, planning scholar Andreas Faludi argued that, without the term ever appearing in Dutch literature, national spatial planning in the Netherlands conformed to all the criteria of a growth management system (Faludi 1994, 493). More recently, Faludi and his coauthors have asserted that the ubiquitous term "spatial planning" (ruimtelijke planning, in Dutch) is best understood as the Euro-English equivalent to "growth management" (Evers et al 2000, 8).

\section{Regulatory Growth Management and Housing Prices}

In the early 1960s, American citizens and elected officials began to voice deep concerns regarding the ecological and fiscal impacts of low-density suburban development. Chief among these concerns were the loss of open space and the threat to environmentally sensitive lands posed by suburban expansion. To address these threats and rein in sprawling development, citizens and their representatives enacted growth management policies "to guide the location, quality, and timing of development" (Porter 1997, vii).

From Hawaii's 1961 "quiet revolution" through to the present-day "smart growth" era, American growth management has taken shape through a wide variety of policy approaches implemented at local, regional, state, and, to a limited extent, national levels (Bengston et al 2003, 272; Weitz 1999). The term growth management can be broadly defined as "a calculated effort by a local government, region, or state to achieve a balance between natural systems—-land, air and water—and residential, 
commercial, and industrial development" (DeGrove 1991).

One common approach to growth management in the United States is to redistribute powers and responsibilities related to development within the layers of government. To counteract the strong tendency for local governments to maximize tax revenue through development, many growth management policies challenge local authority over development decisions and re-assign some or all monitoring and regulatory powers to a regional or state authority (Howell-Moroney 2007, 340). These higher authorities may mandate or strongly encourage local comprehensive planning and may review such plans for compliance with broader (state- or region-wide) planning goals (Weitz 1999). This approach has the potential to bring a broader geographical context and longer time frame to bear on plans for land use and development, which otherwise tend to be determined according to local, short-term priorities.

In addition to this approach of redistributing regulatory powers within the layers of government, auxiliary growth management measures have been implemented with great effect (Howell-Moroney 2007). Such auxiliary measures may take many forms, as evidenced by the typology of growth management policies produced by Bengston $e t$ al (2004). ${ }^{2}$ Beginning with more than thirty distinct policy types observed across the United States, the authors classify the universe of growth management by identifying three basic policy approaches: public acquisition, regulation, and incentives. Viewed as a whole, the typology reveals an approach to growth management characterized by consistent objectives - the management of urban growth and the protection of open 
space-and a diversity of policy tools employed to achieve those objectives (Bengston et al 2004, 275).

Growth management policies have been credited with a wide variety of positive outcomes, from rationalizing public authority over development to reviving neglected urban centers. Most often, the champions of growth management in the United States point to successes in protecting farmland and increasing development density in builtup areas. But growth management is certainly not without its detractors. During the 1990s and 2000s, critics in the United States called attention to skyrocketing home prices and argued that growth management policies were partly to blame. This topic generated countless articles in the academic and popular presses, and at least one edited volume dedicated to its examination, entitled Growth Management and Affordable Housing: Do They Conflict? (Downs 2004).

The argument that growth management contributes to the inflation of home values is advanced most often in reference to regulatory approaches. Examples of regulatory policies for managing urban growth are provided by Bengston et al (2004), and include development moratoria, adequate public facility ordinances, greenbelts, and urban growth boundaries. Put simply, critics of these approaches argue that excessive regulation of development limits the supply of housing relative to demand, thereby increasing the cost of homes in areas affected by the policy. This argument, which is rooted firmly in classical urban economics, suggests that conflicts may exist between the policy objectives of growth management and affordable housing. ${ }^{3}$

The case of Portland, Oregon provides a clear example of regulatory growth 
management and the type of criticism that this approach can generate. In accordance with statewide land use policies, Portland employs an urban growth boundary (UGB) to contain the metropolitan region's peripheral development and protect surrounding high-value farmland. This policy tool, and the unique regional government which oversees its implementation, makes Portland a favorite city of the national growth management community. However, during the 1990s, a sharp increase in area home prices prompted a close examination of Portland's housing market and gave rise to a contentious debate regarding regional growth management policies. Critics alleged that the UGB's limitation on the land available for development inflated land and home prices, thereby threatening the area's historically affordable cost of living. According to this argument, limiting urbanizable land increased the value of that land, causing developers to reduce their housing production or pass increased land costs on to housing consumers directly. Many planners and other analysts came to the defense of the UGB, arguing that area home price increases were better explained by a spike in housing demand driven by population growth, rising wages, and the region's valuable natural and urban amenities (Phillips and Goodstein 2000; Dawkins and Nelson 2002)

\section{Land and Housing Markets}

Although this debate failed to produce definitive answers regarding the relative costs and benefits of Portland's urban growth boundary, one significant point of consensus did emerge from the discussion. Analysts from all camps tended to agree that regional regulation of land supply does, in fact, increase the market price for land 
within the UGB (see, for example, Knaap 1985; Nelson 1985; Nelson 1986).

However, the relationship between the price of land and the average price for finished housing units is extremely complex. While some simplistic models assume a 1:1 relationship between land and housing markets-leading to dire predictions for housing affordability in "managed growth" markets—most analysts agree that the relationship is mediated by a number of intervening variables, many of which are poorly understood. ${ }^{4}$

One much-discussed example of an intervening variable between land and housing markets is that of development density. Citing a tenet of classical urban economics, some analysts of regulatory growth management have emphasized the tendency for housing developers to adapt to increased land costs by reducing lot sizes in order to deliver a finished product with a palatable price tag (Phillips and Goodstein 2000, 336; Nelson and Dawkins 2004). Rising land prices may also encourage a market shift away from single-family residences in favor of higher density alternatives such as multi-family units, granny flats, and accessory units-all of which consume less land per square foot of finished floor area (Nelson et al 2004). As more housing units are accommodated per acre of land, the inflationary effects of growth management regulation may be offset by density increases. This density offset may be further augmented by economies of scale associated with higher-density development, which can lower the per unit cost of infrastructure (Nelson and Knapp 1992).

From a classical economic perspective, then, the effects of an urban growth boundary on per unit housing prices will depend, in part, on the relative strength of 
two countervailing influences: increased land prices and increased density of development (Phillips and Goodstein 2000, 336). Because of the potential to offset land price increases through density gains, planners and policymakers have, in some cases, incorporated density bonuses or minimum density zoning into growth management policy. Arthur Nelson and Casey Dawkins have even suggested that an urban growth boundary is prudent policy only when accompanied by policies that increase development density and intensity $(2004,4)$.

\section{Growth Management in International Settings}

In a 2002 international comparison of urban containment policies, Dawkins and Nelson offer a number of useful findings regarding the interaction of land and housing markets in "managed growth" settings. First, Dawkins and Nelson demonstrate that concerns regarding the effects of regulatory growth management are not limited to the United States. The charge of regulation-induced housing price inflation has been raised and thoroughly debated in the cases of South Korea and the United Kingdom, both of which administer urban containment policies at the national level. Second, the authors find that "it is clear that urban containment programs do affect land prices no matter how they are implemented" (10). This finding is consistent with the consensus view of Portland's urban growth boundary and its effects on area land prices, as summarized above. ${ }^{5}$

However, according to Dawkins and Nelson, the degree to which increased land prices impact area housing markets depends on the design and implementation of a region's larger policy framework for growth management. This finding leads the 
authors to conclude that "the most important policy implication to be gleaned from this review is that local planners play a significant role in determining the severity of housing price inflation attributable to urban containment policies" (11).

In highlighting the role that local decision makers may play in mediating land and housing markets, Nelson and Dawkins stress the importance of "proactive measures" which may stem housing price inflation. Of particular importance are policies that allow planners and/or policymakers to adjust buildable land supplies in response to increased housing demand (Nelson and Dawkins 2004). By adding to the supply of land available for development, decision makers may effectively guide development without limiting housing supply. Furthermore, Nelson and Dawkins (2002) suggest that auxiliary policies designed to increase development densities and/or the production of affordable housing may be necessary to prevent housing price inflation in areas regulated by growth management policies. For reasons discussed above, policies promoting higher density development may offset land price increases. For their part, pro-active affordable housing policies may reduce average home prices by stimulating production of units targeted to low- and moderate-income households.

\section{Problem Framework}

Based on the literature summarized above, this case study rests on the following assumptions:

- Growth management policies which limit the supply of land available for development tend to exert an upward pressure on prices for land within the containment boundary. 
- By increasing the cost of land, regulatory growth management policies may significantly increase average housing costs.

- The degree to which land prices influence average home prices depends on the structure and implementation of the larger growth management policy framework.

- Three specific types of policy appear to be particularly significant in mitigating the impact of land price increases on housing affordability:

- Boundary flexibility: planners and policymakers may be able to stem land and/or housing price inflation by adjusting the supply of land available for development in response to market signals or demographic projections.

- Density increases: planners and policymakers may be able to stem housing price inflation by allowing or encouraging significant density increases within the area available for development.

- Affordable housing policy: planners and policymakers may be able to maintain housing affordability for vulnerable populations by actively promoting increased production of affordable housing.

\section{Statement of Purpose}

In the United States and the UK, a substantial body of literature has been dedicated to analysis and debate regarding the effects of growth management on housing costs. However, despite the Netherlands' long history of managing urban development via national regulations on buildable land supply, relatively little has been written in English about the effects of those regulations on housing affordability. 
Thus, the purpose of this case study is to explore these issues in the Dutch context, with particular reference to the assumptions stated in the problem framework above. The Dutch planning tradition of addressing housing affordability in conjunction with spatial planning makes the Netherlands a particularly ripe setting for this exploratory research.

\section{Unit of Analysis}

At the outset of this research, I was primarily focused on markets and municipal policies in Amsterdam. My initial review of the literature had led me to believe that, of the many tiers of Dutch government, municipalities played the most active role in spatial planning and development policy. Furthermore, as the largest and most cosmopolitan Dutch city, Amsterdam provided the largest quantity of resources (both human and printed) accessible to English speakers. Finally, as my home city, Amsterdam was familiar territory, which facilitated access to interview subjects and added some ground-level perspective to the case study. For these reasons, I conducted many of my early interviews with planning and housing experts in Amsterdam.

However, as my research progressed, I found that the market and policy dynamics that most interested me were difficult to confine to the municipal level. Rather than conforming to the municipal boundaries of Amsterdam, pertinent land and housing markets tend to operate on a metropolitan scale, and in some cases extend to the level of the polycentric mega-region (i.e. the Randstad). Furthermore, the suite of policies that comprise Dutch growth management have most often been designed and 
directed from the national level. For these reasons, I substantially expanded the focus of my research to the national level, and began interviewing experts on mega-regional and national affairs in addition to those focused on Amsterdam. Ultimately, then, this case study is focused on Dutch markets and policies at the national level.

\section{Central Research Question}

How do planners and policymakers in the Netherlands conceptualize and manage the relationship between land and housing markets, and the effects of that relationship on housing affordability?

\section{Methodology}

Following the approaches described in Robert K. Yin's Case Study Research (2004), I will address the central research question in a case study combining elements of description and exploration. The literature reviewed above provides some substantial clues as to the areas of planning and policy of likely significance. From this starting point, I began my research as a descriptive case study, intending to describe the relationship between and management of land and housing markets in Amsterdam in terms recognizable to planners and policymakers in the United States. However, significant social/political/economic differences between the US and the Netherlands required an exploratory approach open to new and unexpected findings.

Broad research questions rest on numerous unstated assumptions and often lend insufficient purchase on the research subject. Explicit study propositions can shed light on embedded assumptions and narrow the scope of research. According to Yin 
(2004), study propositions function to "direct attention to something that should be examined within the scope of study." Two key propositions (A and B) are stated in the research question framework below.

Yin also suggests the development of substantive case study questions, which reflect the actual line of inquiry and serve as reminders to the researcher "regarding the information that needs to be collected and why." Case study questions are listed below in two levels of detail: more general case study questions are numbered, while the most specific case study questions are lettered in the lower-case. ${ }^{6}$

\section{Research Question Framework}

Proposition A:

The understanding of relationships between land and housing markets is likely to be contested territory subject to debate and evolution over time.

1. How do Dutch planners, policymakers, and academic experts conceptualize the relationship between current growth management policy and issues of housing affordability?

A. Growth Management Policy

a. What are the principal objectives of Dutch growth management?

b. At what scale(s) of government is Dutch growth management planned?

c. At what scale(s) of government is Dutch growth management implemented?

d. What are the principal policy tools used to implement growth management?

e. What are the demonstrable outcomes (intended and unintended) of

B. Land Cost Dutch growth management policies and practices?

a. Is it agreed that regulatory growth management policies increase the cost of urbanizable land, or is this a point of debate? 
b. If the above point is debated, what are the relevant perspectives and points of contention?

C. Housing Cost

a. Is it agreed that regulatory growth management policies increase the cost of housing, or is this a point of debate?

b. If the above point is debated, what are the relevant perspectives and points of contention?

\section{Proposition B:}

The relationship between land and housing markets is mediated by the structure and implementation of the spatial planning system.

2. How do planners and policymakers in the Netherlands attempt to influence housing cost through the planning and social housing systems?

D. Development Density

a. What degree of control do planners exert over the density of new residential development?

b. What planning/policy tools are used to influence residential development density?

c. Do planners/policymakers encourage or compel residential density increases in order to offset land scarcity?

d. Is there evidence of a market-based "density offset," in which housing producers respond to land price inflation by increasing development density?

E. Land Supply Adjustment

a. What specific policies determine the supply of urbanizable land at the national level?

b. Is the supply of urbanizable land adjusted in response to market signals, demonstrated public needs, or expressed preferences?

c. If so, what are the demonstrable effects of land supply adjustments on the cost of land and housing?

F. Affordable Housing Policy

a. What object oriented (or supply-side) policies have the greatest effects on the supply of affordable housing units?

b. What subject oriented (or demand-side) policies have the greatest effects on the ability of citizens to obtain affordable housing?

c. What other policies exist to encourage access to affordable housing (e.g. rent regulations; tenant rights)? 
3. To what degree do land costs impact residents' housing costs in the Netherlands?

\section{G. Policy Outcomes}

a. Can an effect of regulatory growth management policies on urbanizable land prices be empirically demonstrated?

b. Can an effect of regulatory growth management policies on housing prices be empirically demonstrated?

c. How are demonstrable cost effects of regulatory growth management (if any) distributed amongst landowners, municipalities, developers, and housing consumers?

d. In terms of housing affordability/accessibility, how does the Netherlands compare to other European nations?

\section{Method of Investigation}

The primary source of data for this case study is a series of semi-standardized interviews conducted with experts in the field: academics, planners, civil servants, and representatives of social housing corporations. Thanks to assistance from my advisors at the University of Amsterdam, I was able to identify local experts who were willing and able to be interviewed in English. In addition to taking the suggestions of my advisors in selecting respondents, I practiced some "snowball sampling," asking each respondent for further leads. In total, I interviewed 19 subjects, representing a wide range of institutions involved in spatial planning. Each interview lasted between one and two hours. Having secured permission from subjects to publish their information for the purposes of this research, I have included a full list of subjects' names and occupations in

Appendix D. 


\section{SECTION II: GROWTH MANAGEMENT IN THE POST-WAR PERIOD}

\section{Scope and Intergovernmental Structure of Dutch Spatial Planning}

In 1971, a special commission of the Dutch national government broadly defined the scope of spatial planning in the Netherlands. According to the commission, spatial planning operates “in society's best interest, to search for, and work towards, the best possible mutual adjustment between the physical environment and society" (quoted in Faludi 1994, 502). This definition built on historic traditions of public land management in the Netherlands, wherein the state acted to balance demands on the limited supply of dry, buildable land. However, the commission's definition significantly expanded the domain of spatial planning, "from mere land-use regulation to the comprehensive management of the environment," and implied the integration of traditional policy sectors concerning development and the natural environment (Faludi 1994, 502). Although it was written in 1971, this definition nicely captures the expansive role played by Dutch spatial planning throughout much of the late 20th century.

At the national level, these broad planning powers are exercised by the Ministry of Housing, Spatial Planning and Environmental Policy, or Ministerie van Volkshuisveting, Ruimtelijke Ordening en Milieubeheer (VROM). Commonly known by its Dutch acronym, VROM is responsible for producing and periodically updating the National Spatial Strategy, or Nota, which functions as a national spatial plan (Needham 2007, 135). In the Nota, VROM lays out broad objectives for spatial and environmental policy at the national scale, often with a time horizon of twenty to thirty 
years. The Nota also addresses intergovernmental coordination, and "says more than what the national government intends to do: it says also what the government wants municipalities and provinces to do in order to realize the national spatial planning policies" (Needham 2007, 136).

For many foreign researchers interested in Dutch spatial planning, VROM's National Spatial Strategy is an obvious point of entry. The Ministry goes to significant lengths to make its policy documents accessible, rolling out Notas as full-color booklets replete with maps and graphics, written in clear language and published in Dutch, English, French, and German. As economist and planning scholar Barrie Needham (2007) has noted, this public relations effort has a significant effect on the image of VROM, especially in the eyes of foreign observers. Many scholars visiting from abroad leave the Netherlands under the impression that, as author of the National Spatial Strategy, VROM is the most influential player in a hierarchical system of centralized spatial planning (Needham 2007, 121).

The reality of Dutch spatial planning is far more complex. The structure of governance in the Netherlands is best described as a decentralized unitary state, in which "public powers are distributed between the three layers of government, each of which has a certain amount of autonomy (the powers are decentralized); [...] nevertheless none of those three levels may take actions which contradict the actions of the other levels (the state is unitary)" (Needham 2007, 142). In this system, formal hierarchical powers are invoked only as a last resort. Instead, the work of governance is accomplished through negotiation, compromise, and consensus-building (van der 
Valk 2002, 205). Barrie Needham (2007) explains the significance of this system of governance for the work of spatial planning:

In a strict hierarchical system, the national government determines spatial planning policy in general, the province works that out for its own area, the municipality works it out further in detail. Those are not the rules in the Netherlands. All three levels make spatial policy for their areas at the same time, existing plans remain valid even though they no longer conform to the policy of higher levels, there is a continual shifting of policies and a continual mutual influencing between the three levels. (143, emphasis added)

Because of this interdependence and mutual influence between layers of government, a full exploration of Dutch growth management would necessarily address formal policies and informal relationships at and between the many levels of government: national, provincial, regional, municipal, and sub-municipal (stadsdelen). For obvious reasons, such a thorough exploration of Dutch governance is well beyond the scope of this case study. Instead of aiming for a comprehensive treatment of the subject, I will focus here on the aspects of Dutch growth management emphasized most often in the literature, and by the planning experts I interviewed.

FIGURE 1: Layers of Government and their Areas of Planning Responsibility

\begin{tabular}{llll}
\hline Tiers of government & Legal spatial plan & Area & Content \\
\hline Central government & Planning core decision & All of the country & Broad national policy guidelines \\
Provinces (12) & Regional structure plan & $\begin{array}{l}\text { Province or part of a province } \\
\text { Municipality or combination } \\
\text { Municipalities (500) }\end{array}$ & $\begin{array}{l}\text { An overview of provincial planning policy } \\
\text { of municipalities }\end{array}$ \\
& Land allocation plan & Part of a municipality & Binding maps and regulations \\
\hline
\end{tabular}

Source: van der Valk (2002), pp. 206. 


\section{The Role of National Planning}

"There is a firm conviction that national government is responsible for the evolving pattern of urbanization but that, preferably, it should not resort to compulsion to get its views accepted. Plans are indicative, and national planning is primarily the generator of ideas. Reserve powers of issuing national directives are used with great circumspection."

(Faludi 1992, 101)

This passage neatly captures a sentiment I heard expressed time and again in interviews: VROM does not generally rely on formal hierarchical power to implement the National Spatial Strategy. To be sure, Dutch law does grant the national government certain hierarchical powers over lower tiers of government, including powers to review, veto, and re-write certain land use plans originating at the municipal and provincial levels. ${ }^{7}$ However, the act of invoking statutory power is seen as a sign of poor negotiation skills and as an admission of administrative failure, and is therefore considered the option of last resort (Needham 2007, 145; van der Valk 2002, 205).

When asked about the role of national planning, the experts I interviewed seemed to agree that VROM's most important contribution is in "setting the tone" for spatial planning in the Netherlands. By periodically updating and widely distributing the National Spatial Strategy, VROM gives currency to a common set of concepts and objectives to be discussed and pursued throughout the vast Dutch planning 
community. This view of VROM's influence is substantiated by two of the preeminent scholars of Dutch spatial planning, Andreas Faludi and Arnold van der Valk. In their 1994 book entitled Rule and Order, Faludi and van der Valk argue convincingly that the planning successes of the 1970s and 1980s relied not on a specific set of policy tools or formal state powers, but on a consensus-based planning doctrine that shaped the assumptive world of planners. This planning doctrine did not develop spontaneously, but reflected VROM's efforts to clearly define the problems confronting Dutch society and to indicate specific planning solutions to those problems (Faludi 1992, 99-100).

Important as this form of "soft power" may be, the influence of VROM is not limited to shaping the assumptive world of Dutch planners. When discussing the role of the national government, interview subjects also emphasized the importance of the "golden strings" of national subsidies. Provincial and municipal governments in the Netherlands collect only a small fraction of their total revenues from local sources. For municipalities, $19 \%$ of total revenue is collected locally; for provinces, the figure is $24 \%$ (2005 figures). The rest comes in the form of transfers from the central government- transfers which often carry very specific provisions for the use of funds (Needham 2007, 143). According to some interview subjects, these provisions represent the most influential form of national planning in the Netherlands. "He who pays the piper calls the tune," as Faludi and van der Valk note. "Even where there are no formal powers of direction, if it puts its mind to it, central government can persuade municipalities to follow its policies. Formally, municipalities are autonomous. In fact 
they are dependent on central government." (Faludi and van der Valk 1991, 46).

\section{The Role of Municipal Planning}

When asked to identify the level of government with the most direct influence over development in the Netherlands, experts invariably point to the municipality. This unparalleled influence is exerted through two distinct processes: the issuing of building permits, and the supplying of land prepared for development.

\section{Building Permits and "Postage Stamp Planning”}

In the Netherlands, the municipal government retains exclusive power to issue or deny building permits, which are required by law before any development can commence. This exclusive power gives municipalities a trump card in negotiations with private developers, and with planners at other levels of government. In addition to municipal building codes, permit applications are subject to an "aesthetic test" conducted by an independent panel of experts (e.g. architects and designers.) More importantly, the building permit is used to implement and enforce the municipal land use plan, which can specify detailed land uses and design requirements including building placement and the mass, height, and density of development (Needham 2007, 130).

Dutch planning law requires municipalities to produce a land use plan for all open space existing within municipal boundaries. This bestemingsplan is primarily regulatory in its function: it is most effective as a tool for maintaining the status quo 
(Needham 2007, 132). When considering building permits for proposed new development, municipal planners compare the proposed use to the bestemingsplan. If the proposed use is not allowed under the existing bestemingsplan, the building permit is denied. In this way, planners utilize control over the building permit to regulate development in accordance with the municipal plan. This is the most direct form of regulatory growth management available to planners in the Netherlands.

However, when municipal planners would like to see a change in land use occur, as in the case of desired greenfield development, the law allows them significant flexibility. Under Dutch law, the bestemingsplan can be amended for areas of any size. Municipal planners frequently utilize this flexibility to plan at the scale of individual developments, drawing up site-specific plans authorizing the land uses proposed by a developer. As a result of this practice of "postage stamp planning," small land-use plans proliferate in the Netherlands. For example, the municipality of Nijmegen, with 160,000 residents, had 840 valid land use plans on the books as of November 2006 (Needham 2007 130).

Of course, drawing up new land use plans takes time: "If the procedures are followed as quickly as is allowed, and if there are no objections and appeals, it can take between 43 and 62 weeks to make a new plan" (Needham 2007, 160). In situations where planners and developers prefer to move faster—and there are many of these-planners have the power to approve a non-conforming building permit by stating that the proposed use conforms to a new bestemingsplan which is still in the works. In practice, many of these ostensibly forthcoming land use plans are never 
completed, and the non-conforming use is allowed to stand (Needham 2007, 160-162). According to Barrie Needham, "nobody bothered much about the misuse of the planning law [in this manner], until the national government decided that it was so widespread that it made a mockery of the claim that the planning system gave the citizen legal certainty" (161).

Recently, the national planning law has been amended to reduce the flexibility of planning at the municipal level, and to increase the predictability and certainty of the planning system for developers and citizens. Nevertheless, municipal planners retain a great deal of discretionary power when it comes to enforcing the bestemingsplan. When it is needed, the bestemingsplan can be rigidly enforced via the building permit to preserve open space. And when development is desired, municipal planners have plenty of available avenues through which non-conforming proposals can be approved and realized (Needham 2007, 160-162).

\section{Supplying Buildable Land}

Because of the high water table and prevalence of unstable peat bogs in the Netherlands, real estate development is only possible after a complex and expensive process of land preparation. This is especially true in the west of the country, where elevations are lowest, and where most of the Dutch population resides. Generally speaking, land must be drained, pumped dry, and filled in with sand and other stabilizing material before infrastructure can be added and building can commence. More intensive forms of development can require far more complex and costly land 
preparation, e.g. the sinking of stabilizing rods deep into the marshy soil. ${ }^{8}$

Traditionally, developers of housing and commercial buildings have been extremely limited in their capacity to prepare land in this manner. Since the late 18th century, municipal governments have taken responsibility for this task, supplying prepared land as a public good to allow for development (Faludi and van der Valk 1991, 46).

Throughout much of the twentieth century, private real estate interests were dependent upon municipal governments for a supply of buildable land, giving public officials considerable control over the pace and location of development. Andreas Faludi (1994) elaborates on the implications of this dependence for municipal planning:

The municipality can stipulate what has to be built, when, by whom, for whom, at what price, and so forth. It can put its land policy at the service of planning. This is indeed what happens. Municipalities provide as much as 80 per cent of land coming into development. [...] Here is a unique feature of Dutch planning, if ever there was one. (496)

Although the municipal government's monopoly on land preparation has recently been challenged by private developers, many municipalities remain the primary suppliers of prepared land. Under Dutch law, state agencies enjoy the same rights of property ownership as individuals. Because of this, municipalities are able to attach detailed conditions to the sale of public lands, including "when the building must start and when it must be completed; the price of housing to be built; [and] whether [the housing] is for sale or for rent." (Needham 2007, 184). 
By preparing and selling land with conditions attached, municipal authorities are able to control the buildable land base through "just in time" delivery, adjusting land supply relative to demand in order to encourage desired land uses (Korthals Altes 2008, 8-9). Furthermore, as dominant players in the land market, municipalities can often influence land prices, and can elect to subsidize desired forms of development by providing prepared land at reduced cost. ${ }^{9}$ This price-setting power also allows municipalities to cross-subsidize development by channeling the surplus captured from more profitable forms of building into social goods such as affordable housing, green space, or infrastructure (Needham 2007, 186; Faludi and van der Valk 1991, 46). Through this system of cross-subsidies, municipal planners control large surpluses, which can be used to stimulate desired forms of development.

\section{Growth Management and the Combination of Positive and Negative Planning}

In the typology cited in the introduction above, Bengston et al (2004) divide the universe of growth management policy into three basic categories: public acquisition, regulation, and incentives. In the Netherlands, spatial planners draw a similar distinction between "planning by permission" (toelatingsplanologie) and "planning for development" (ontwikkelingsplanologie) — essentially collapsing three categories into two by combining public acquisition and incentives under the heading of "planning for development."

Planners from abroad may look at the Netherlands and see a highly regulated system of land management featuring rigid restrictions on greenfield development. 
Dutch planners, however, tend to see themselves as facilitators of appropriate development. According to Barrie Needham (2007), the term for negative/regulatory planning (toelatingsplanologie) "is used [by Dutch planners] in a rather derogatory sense. For, it is argued, land use planning should not be about stopping people changing the use of land...Land use planning should encourage development (called approvingly 'ontwikkelingsplanologie')" (172).

The tendency to favor planning for development is rooted in the Dutch tradition of reclaiming land and building infrastructure for water management, which confers near-heroic status to builders, developers, and civil engineers (Needham 2007). In the Netherlands, "the builders push society forward. Land use planners are expected to help them in their pioneering work. If planning proposes that, nevertheless, some areas be protected from further development, planning is expected to put forward alternative building locations: development can be controlled and steered in the interests of good planning, but it should not be discouraged" (Needham 2007, 27).

While Dutch planners may favor development-oriented positive planning over regulatory negative planning, scholars agree that growth management in the Netherlands is characterized by the balanced coordination of these approaches (Korthals Altes 2006, 103; see also Siraa et al 1995, 29; Cals et al 1966, 195). In his studies of Dutch spatial planning, Andreas Faludi argues that "successful growth management has two faces: first, the prevention of growth where it should not occur; second, the provision for commensurate growth (with facilities included) in other designated areas" (Faludi 1994, 486; see also Faludi 1992, 93). Reflecting this balance 
between regulation and stimulation, growth management has been pursued on a national scale as the agricultural "Green Heart" of the country has been kept open while development has been encouraged within a conurbation known as the Randstad.

\section{Preserving the Green Heart}

The preservation of open space for agricultural and recreational uses has been a top priority of national spatial planning since shortly after World War II. During post-war reconstruction, proponents of growth management emphasized the threat that disorganized development posed to the nation's food supply and economic wellbeing. To prevent a "sea of houses" from consuming the nation's farmland, supporters lobbied for the strict preservation of agricultural and recreational functions in the "Green Heart" (Het Groene Hart), a large open area located in the center-west of the Netherlands (Zonneveld 2007, 663). After coasting for a time on rhetorical power alone, the Green Heart concept was formalized and adopted into national spatial planning policy in the 1960s (Koomen et al 2008, 365). 


\section{FIGURE 2: The Green Heart}

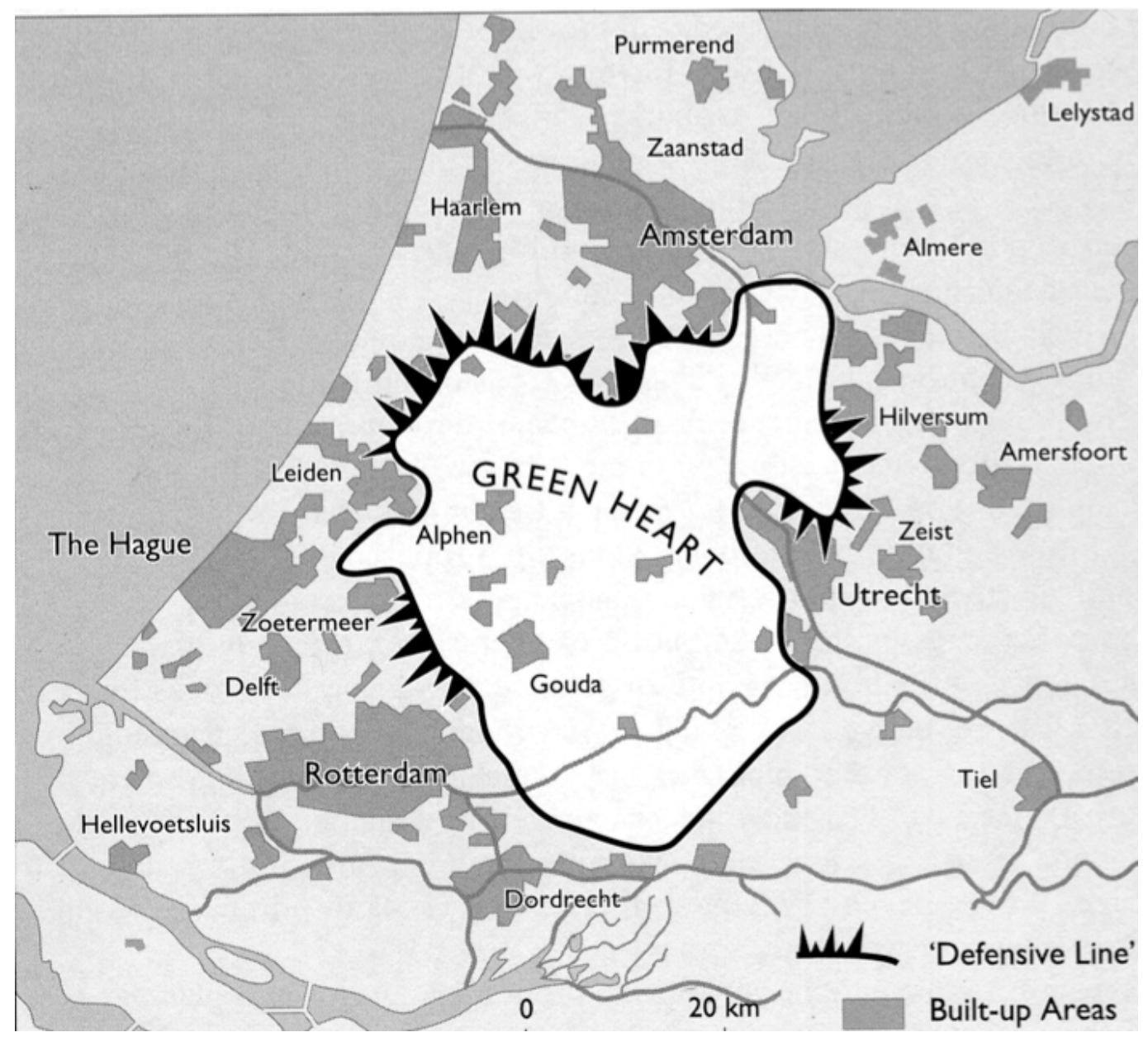

The Green Heart, surrounded by the "defensive line" of national spatial planning. As presented by Faludi and van der Valk (1994).

In the effort to preserve agricultural and recreational functions in the Green Heart, the power of municipalities to implement national planning directives has been essential (Zonneveld 2007, 659). This implementation process consists of two steps: first, the municipality adopts a local land use plan conforming to the national plan for open space preservation. Subsequently, the municipality can enforce its local plan via control of the building permit (Faludi 1994, 493; 498) ${ }^{10}$ By refusing to grant permits 
in planned open areas, the municipality can effectively prevent all development in locations that the national government has designated for agricultural and recreational uses. In this way, municipal control of the building permit has been used with great effect to implement national preservation policies (Needham 2007, 171).

A secondary approach employed in the broader effort to separate town and country is the green "buffer zone." Functioning as wedges between growing cities, buffer zones are designated open areas strategically employed by the national government to prevent conurbation (Needham 2007, 91). As in the case of the Green Heart, buffer zones are implemented via adoption into local land use plans and enforced through the building permit system. In total, ten buffer zones have been designated, ranging in size from 3 to 8,700 hectares (Koomen et al 2008, 361-377). By combining buffer zones with the Green Heart preservation strategy, national spatial planners have managed to preserve $87 \%$ of surface area in the Netherlands as open space. Of that open space, about $75 \%$ (or 69\% of national land area) is dedicated to agricultural functions (Koomen et al 2008, 364).

\section{Structuring Urbanized Areas}

In addition to preserving valued agricultural land and recreational opportunities, open space preservation policies perform the function of structuring urbanized areas. The urban counterpart to the Green Heart concept is the Randstad, or "rim city," a term that describes the urbanized band connecting the four largest Dutch cities: Amsterdam, Rotterdam, the Hague, and Utrecht. This band of cities and towns, 
which is home to over half of the Dutch population, stretches along the Western coast of the Netherlands and defines the outer edge of the Green Heart. ${ }^{11}$

During the initial period of postwar national planning, the Randstad agglomeration was strengthened through limitations on development in the Green Heart. Then, in 1974, VROM announced a policy of "bundled deconcentration" designed to accommodate population growth in strategic locations within the Randstad, thus adding further strength to the established rural/urban contrast in the West of the country (Faludi 1994, 493). In total, VROM designated fifteen new and growing townsdecision makerlocated within the Randstad belt but outside major citiesdecision makerto act as growth centers by accommodating new development. In the early 1980s, at the peak of the "bundled deconcentration" era, close to one quarter of all new housing development in the Netherlands took place within growth centers (Faludi 1994, 493). This strategy allowed for a controlled dispersal of population, and was seen as the only alternative to widespread suburbanization (Faludi and van der Valk 1991, 47).

In keeping with the overarching strategy of combining restrictive and stimulative planning measures, VROM executed the "bundled deconcentration" strategy by coordinating development regulations and subsidies. In total, VROM channeled an estimated 4.5 billion guilders to stimulate the development of growth centers (Faludi and van der Valk 1991, 48). These subsidies were used to finance infrastructure, housing, and the additional administrative costs borne by the effected municipalities (Faldui and van der Valk 1991, 47). In this way, the central government 
balanced strict restrictions on development in the Green Heart, offered a massive down payment on the growth centers policy, and set the scene for significant private investment.

\section{The 'Marriage of Convenience' and the Housing Imperative}

The policy of "bundled deconcentration" provides one example of the strategic alliance formed between national spatial planning and housing efforts (Faludi 1994). In this "marriage of convenience," which lasted from the 1960s through the 1980s, urbanization policies directly supported open space preservation by absorbing development pressure, while access to the Green Heart made dense urban living palatable for residents of the new "growth centers." However, while this partnership has often been described as a "marriage" (Faludi 1994), the balance of power between partners was far from equal. Because of a chronic housing shortage in the postwar period, the provision of new housing en masse was seen as the highest priority of spatial planning (Rouwendal et al 2004, 7). When necessary, agricultural preservation goals and other spatial objectives were sacrificed to the dominant concern for housing supply.

During the heavy battles and bombing raids of World War II, the Dutch building stock suffered extensive damage. Of the 2.1 million homes that existed in 1940, 82,000 were destroyed and 45,000 heavily damaged by the war's end, leaving scores of families without adequate shelter (Siraa 1989, 43; quoted in Faludi 1994, 490). Immediately following the war, this critical housing shortage was compounded by 
demographic shifts, as a national baby boom coincided with rapid industrialization and an attendant wave of urban in-migration (Faludi and van der Valk 1991, 45). The net result was a national housing supply that fell woefully short of demand. During the 1950s, overcoming this deficit and providing housing for a fast-growing urban population became the highest priority for Dutch spatial planners.

The national government's response to the postwar housing crisis has been described as "the most ambitious social housing program ever attempted that set as a national commitment that all Dutch citizens should be adequately housed." (O’Loughlin, as quoted in Faludi 1994, 504). To fulfill this commitment, the Dutch government partnered closely with non-profit housing associations. Formed in the late 19th-century as a secondary support to the private market, non-profit housing associations had played a relatively minor role in Dutch society during the first half of the twentieth century (Priemus 2003, 329). However, after the second world war, while private investment in housing production lagged, the national government found it could orchestrate "a high volume of new construction through the not-for-profit sector with relative ease" (Milligan et al 2006, 240).

Working in cooperation with municipal planning departments, the national government marshaled public control over land supply to confer large subsidies to non-profit housing associations (Needham 2007, 67). By draining, filling, and stabilizing marshland and adding basic infrastructure for development, "the State paid about two-thirds of the average land costs per dwelling and demonstrated its readiness to run great financial risks." (Priemus 1998, 31). In this way, subsidies from the 
national government kick-started a massive program of social housing development with the objective of providing adequate shelter to all citizens. As they churned out expansive housing developments that conformed neatly to the wishes of national and municipal planners, non-profit housing associations assumed a central role in the burgeoning Dutch welfare state (Priemus 2003, 329)

Largely as a result of the national building program of the postwar decades, nearly one third (31\%) of the modern Dutch housing stock is in multi-family apartment-style developments (Pellenbarg and van Steen 2005, 133). In the Randstad cities of Amsterdam, Rotterdam, and the Hague, multi-family developments are particularly common, comprising up to $75 \%$ of the local housing stock (Pellenbarg and van Steen 2005, 594). Two- to four-story row houses typical of the pre-WWI era comprise $42 \%$ of the national housing stock, while semi-detached and detached units are in the minority, comprising $14 \%$ and $13 \%$ of the housing stock, respectively (Pellenbarg and van Steen 2005, 133).

By US standards, average housing densities are moderately high in the Netherlands, at approximately 12 housing units per acre. Furthermore, the range of housing densities across district types is fairly narrow, with central urban areas averaging 20 units per acre and small villages averaging 8 units per acre (Brouwer $2000,316)$. It is worth noting that, at 7.6 units per acre, average housing density in the United States is roughly equivalent to that of small Dutch villages (Ewing et al 2008, 19). Statistics illustrating additional characteristics of the Dutch built environment are provided in Figure 3, below. 
FIGURE 3: Relative Incidences, Areas and Population Densities of

\section{District Types}

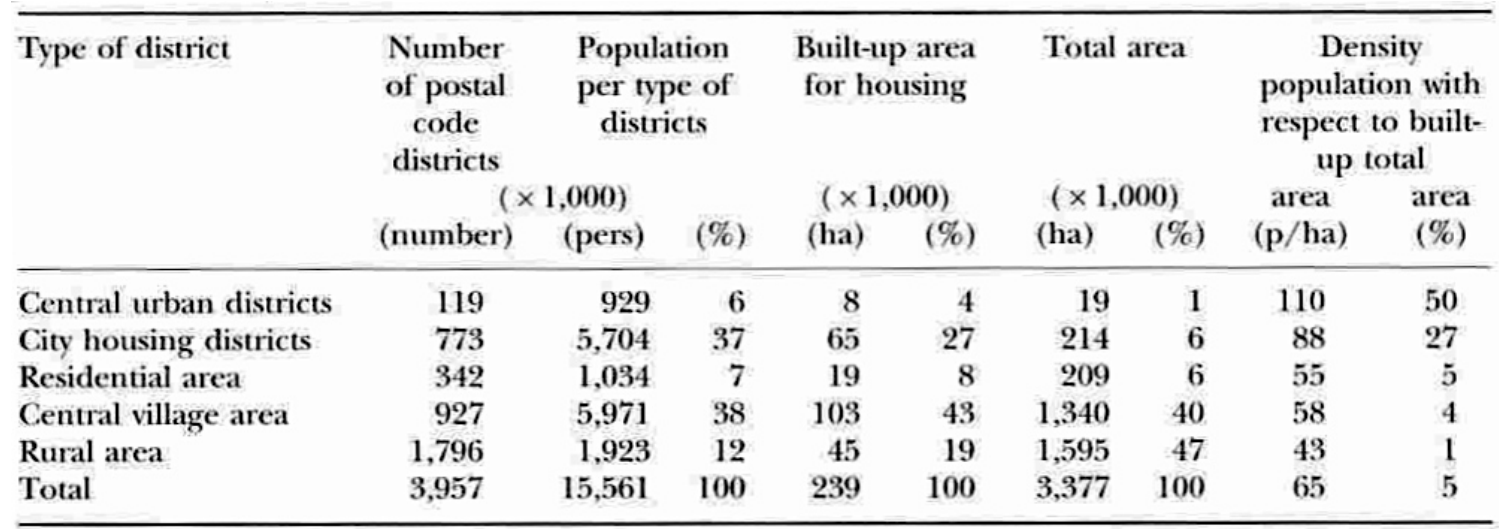

Source: Brouwer (2000), pp. 320.

\section{Section II Summary}

This section has provided an overview of Dutch growth management efforts beginning with post-WWII reconstruction and continuing through to the "bundled deconcentration" era, which lasted until the late 1980s. During this period, growth management was pursued on a national scale in the Netherlands, as open space was preserved in the Green Heart and designated buffer zones while development was encouraged within the Randstad conurbation.

The strategy of Green Heart preservation was championed by VROM and implemented through a combination of national and municipal policies. After introducing key concepts such as the Green Heart and the Randstad into the national 
planning doctrine, VROM channeled resources and coordinated with municipal governments to enact a strategy of "bundled deconcentration." Massive investments of national funds into the development of growth centers and into the non-profit housing sector were essential to the strategy of "bundled deconcentration," and provide an example of VROM's "golden strings" of influence. However, vertical coordination between layers of government was also essential to the growth management efforts of this era, as municipal governments adopted the Green Heart into local spatial plans and enforced development restrictions through control of the building permit. Research by Geurs and van Wee (2007), based on the construction and analysis of alternative development scenarios, suggests that national growth management policies had significant effects on urban form during the period 1970-2000, reducing automobility and limiting the conversion of open space to urban uses.

\section{Reflections on the Problem Framework}

In the problem framework guiding this research, I state that growth management policies which limit the supply of land available for development tend to exert an upward pressure on prices for land within the containment boundary. Furthermore, I suggest that, by increasing the cost of land, regulatory growth management policies may significantly increase the average housing cost. However, during the period outlined above, it would appear that Dutch growth management policies did not significantly impact average housing costs in the Netherlands. Two features of Dutch spatial planning help to explain this phenomenon: flexible land supply, and subsidies 
to non-profit housing developers.

Research into historic land values has demonstrated that during the "bundled deconcentration" era, "the supply of developable land was so large that there was no value increment between agricultural land value and land designated for urban land development" (Korthals Altes 2008, 8). The inflation of urbanizable land value was prevented through a careful balance of development restrictions and subsidies, which accommodated development pressure in strategic locations. As Barrie Needham has argued, maintaining that balance was a central objective of spatial planning during the 1960s, 70s, and 80s: "One of the main functions of land use planning in those decades was to make land available for housing development. The locations were determined in consultation between national and local government, the land was acquired and serviced by local government. [...] It is no wonder that, in that period, there was great conformity between the planning policy for housing locations and the results on the ground" (Needham 2007, 67).

In point of fact, Dutch spatial planners did not place absolute limits on the supply of land available for development during this period. Instead, the area of developable land was strategically increased over time in response to local demands for housing and development, while consistent pressure from the national government ensured that the Green Heart and buffer zones remained largely dedicated to open space. In keeping with the decentralized unitary state model of governance, this approach was characterized by constant negotiation and compromise between municipal and national governments. Much like a flexible urban growth boundary, this 
approach allowed development to be steered to strategic locations (e.g. growth centers) without placing absolute restrictions on land supply.

When discussing average housing costs during the "bundled deconcentration" era, it would be difficult to over-state the impact of non-profit housing development. Supported by subsidies in the form of direct infusions from the national government and prepared land from municipalities, the Dutch social housing stock grew by more than $620 \%$ between 1947 and 1981 (Milligan et al 2006, 240). At the peak of social housing production in early 1980 s, $90 \%$ of housing starts in the Netherlands were subsidized in this fashion (Faludi 1994, 497). By the early 1990s, at the end of the "bundled deconcentration" era, Dutch housing associations owned and operated 44\% of the national stock (Boelhouwer 2002).

As I have stated in the problem framework above, policies promoting the development of affordable housing have the potential to offset land price increases that may result from growth management regulations. In the case of the Netherlands, affordable housing development was not an auxiliary policy designed to mitigate unintended outcomes, but a cornerstone of the "bundled deconcentration" strategy. During this period of Dutch growth management, Europe's most aggressive program of open space preservation was matched by Europe's most ambitious social housing program. 


\section{SECTION III: GROWTH MANAGEMENT IN THE 1980s AND 1990s}

\section{The Recession of the 1980's}

After decades of sustained economic growth fueled by a post-war industrial boom, a deep recession hit the Netherlands in 1980. Climbing steadily from five percent in 1979, the national unemployment rate reached double digits in 1982 and hovered in the range of ten percent until the end of the decade. With nearly two-thirds of the population collecting public benefits while national economic growth stagnated, it suddenly appeared that the Dutch welfare state was vulnerable to collapse, and a new set of buzz words came to dominate domestic politics: deregulation, decentralization and privatization (Faludi and van der Valk 1994, 176).

A new right-of-center governing coalition stepped into power in 1982, emphasizing free markets and economic competitiveness while slashing public spending. In this climate of fiscal austerity, the "marriage" of spatial planning and social housing came under intense scrutiny. This is reflected in the fourth edition of VROM's National Spatial Strategy, which was drafted at the height of the recession in the mid-1980s. The report downplayed traditional growth management themes, instead emphasizing the need to safeguard the nation's economic position. According to Faludi (1994), "the secret agenda [of the Fourth Report] was to reprogram planning from a policy essentially concerned with housing" and open space, "to one concerned with economic restructuring, including the necessary infrastructure provisions" (495). At the same time, the national government initiated a rapid draw-down of subsidies for social housing in an effort to cut the golden strings supporting non-profit housing 
associations. In an era of staggering national debt and stagnant economic growth, housing subsidies had lost their base of support in the Dutch parliament (Priemus 1998, 32).

However, by 1993, economic and political winds had shifted in the Netherlands. Just three years after the Fourth Report was finalized, VROM published the "Fourth Report - Extra" with backing from a new left-of-center governing coalition. In spite of its title, which suggests a reinforcement of the original Fourth Report, the 'Extra' version broke from its predecessor and returned to traditional spatial priorities of Dutch planning, "refocusing on the Randstad and Green Heart complex of ideas... and instituting yet more stringent restrictive policies in the Green Heart" (Faludi 1994, 495).

With the publication of the Fourth Report - Extra, growth management returned to its central position on the national planning agenda. However, the preceding decade of recession and fiscal austerity had taken its toll on the alliance between spatial planning and housing. This section will elaborate on the Fourth Report-Extra, the privatization of social housing provision, and the effects of these developments on land and housing markets in the Netherlands.

\section{The VINEX Era}

The publication of VROM's Fourth Report - Extra was a watershed moment in the history of Dutch growth management policy. The report, which is commonly known by the acronym VINEX (Vierde Nota Ruimtelijke Ordening - Extra), marked 
the end of the "bundled deconcentration" era, and the introduction of a new doctrine in Dutch spatial planning: the compact city.

The VINEX report was based on a projection of substantial population growth and attendant demand for new housing. VINEX authors estimated a need for 835,000 new homes in the Netherlands between the years of 1995 and 2015. The majority of that growth (485,000 homes) was expected to occur in and around the built-up area of the Randstad (Faludi and van der Valk 1994, 220). Rather than dispersing development into nodes of "bundled deconcentration" removed from established city centers, VINEX directed provinces and municipalities to develop according to a strict set of location priorities designed to reinforce existing patterns of urbanization. Reflecting the rise of environmentalism in Dutch planning circles during the 1980s, compact city policies were designed, above all, to limit automobility and support alternative modes of transit (Priemus 1998, 33).

With the conclusion of the "bundled deconcentration" era and the attendant emphasis on housing provision, the preparation of ample land supplies to facilitate new development came to an end (Vermeulen and Rouwendal 2007). The new compact city approach emphasized infill development, giving top priority to sites within urbanized areas. If these sites offered insufficient development capacity, sites on the edges of existing urban areas would be developed at densities comparable to the urban core. As a last resort, new urban nodes would be established in greenfield locations, provided that they were situated as close to existing cities as possible (Needham and Faludi 1999, 482). Under this compact city model, "urban regions 
would function as compact daily urban systems. Concentration policies were there to maintain support for urban services, to limit mobility growth, to allocate housing, employment, and facilities in order to optimize accessibility by bicycle and public transport, and to contain the further urbanization of rural areas" (Korthals Altes 2006, 102).

Heightened environmental concerns were also reflected in stronger and more rigid protections for open spaces under VINEX. To maintain the viability of agricultural and recreational uses of open areas, VINEX featured a "hardened" border surrounding the Green Heart and strict limitations on rural development. Throughout the preceding era of "bundled deconcentration," VROM's spatial planners had relied primarily on strong rhetoric and negotiating skills to protect the Green Heart from urban encroachment (Zonneveld 2007, 663-665). However, "in the VINEX, for the very first time, a line was drawn on the map to mark the boundary of the Green Heart [...] In 1997, this line acquired legal status as a 'concrete policy decision’ [...] meaning that the provinces were obliged to include this line in their plans" (Zonneveld 2007, 668). By extension, this development also required municipalities to respect the Green Heart's newly formalized boundary, and to defend it with the power of the building permit.

Within the Green Heart and other protected areas, towns and villages were allowed to plan for development only when new housing was required to accommodate "indigenous need." Under pressure from VROM, provincial authorities enforced this policy by demanding proof of natural population increases before 
approving municipal land use plans for development (Faludi 1992, 95). Although this form of growth control had been introduced in the era of "bundled deconcentration," VROM further tightened the restrictions on rural development under VINEX (Evers et al 2000, 12).

\section{Continued Privatization}

In addition to intensified policies containing urban growth and limiting rural development, the VINEX era featured a marked shift away from central government subsidies for local development. Reflecting the impact of the recent recession, the VINEX authors reinforced the theme of privatization introduced in the Fourth Report by emphasizing the importance of public-private partnerships while signaling a disengagement from large-scale stimulative planning (Faludi and van der Valk 1994, 222; Faludi 1992, 104). The central government's role in supporting social housing was thought to be particularly problematic. Writing one year after VINEX publication, Faludi and van der Valk (1994) hinted at things to come: "The [national] government is critically reviewing its housing role against the background of a wholesale reappraisal of the welfare state. Subsidies are generally looked at with suspicion. The consensus is that the Dutch need to be weaned of them" (228).

In fact, the "marriage" of spatial planning and social housing had been under threat since the mid-1980s, when the central government initiated a precipitous drawdown of annual loans to non-profit housing developers. In 1988, the Ministry of Housing published a policy memo entitled "Housing in the Nineties," which promised 
a steep reduction in annual subsidies toward the operating costs of social housing associations (Priemus 1998, 32). Negotiations between the central government and representatives of the housing associations commenced, focusing on the task of privatizing the housing associations and disentangling the Dutch government from its de facto ministry of social housing production. In 1995, privatization was finalized when the parties swapped debt obligations and agreed to go their separate ways. In this arrangement, the central government collected in full the debt it was owed by the social housing sector (approximately EUR 17 billion) while simultaneously paying out promised subsidies in a lump sum of more than EUR 16 billion (Priemus 2003, 330). In addition to the payout, housing associations received a great deal of operating freedom in the arrangement (AEDES 2007). However, they also assumed the responsibility to act as private entities, taking on attendant financial risks and competing for market position with private developers.

\section{From Steering Growth to Limiting Land Supply}

At the time of VINEX publication in 1993, the privatization of social housing was well under way, and the sector's strategic alliance with spatial planning had already broken down. In search of a new partner to help execute plans for development, VROM looked to private developers of higher-valued ownership housing. Thus, in the new development areas identified in VINEX, VROM imposed a maximum limit of $30 \%$ social housing, leaving $70 \%$ of housing to be supplied by private developers (Needham and Faludi 1999, 488). To appreciate this policy as a 
limit on social housing production, it should be recalled that in the early 1980 's, at the peak of investment in the growth centers, $90 \%$ of housing starts nationwide had been subsidized (Faludi 1994, 497). This limitation on social housing was designed to increase the proportion of higher-valued homes, in part to accommodate more- middle and upper-income households within city centers and the new VINEX developments (Korthals Altes 2007, 1503-1504).

With reduced capacity to subsidize municipal development directly, VROM introduced a new approach to land preparation designed to make up for the shortfall. As I have discussed above, growth management policy during the "bundled deconcentration" era had featured a steady supply of land available for development in order to prevent the inflation of urbanizable land values. In the VINEX era, VROM did an about-face, intentionally limiting the supply of land relative to demand so as to drive up urbanizable land values and increase the surplus generated by municipal land developers (Evers et al 2000, 11; Faludi and van der Valk 1994, 225). This spatial strategy was augmented by the shift to increased ownership housing, which was expected to result in higher market values for developable land (Needham 2007, 193). Needham and Faludi explain the reasoning behind this aspect of VINEX policy: "the more effective restriction on development outside the city region should increase the price of building land within the city region, thus permitting the municipalities to cover out of land sales more of the infrastructure costs, thus reducing the need for governmental subsidies" (Needham and Faludi 1999, 487).

In other words, in the VINEX era, VROM marshaled rural growth limitations 
and a "hardened" boundary protecting the Green Heart to limit the supply of land available for development. By driving up urbanizable land cost, this policy was intended to make the business of land preparation more profitable for municipal governments. The increased surplus gained from preparing land for development could then be used to finance publicly supplied infrastructure, open space, and-to a limited extent—social housing.

\section{The Great Miscalculation}

The policy of limiting land supply to increase municipal revenues rested on a critical assumption: namely, that municipal governments would retain their dominant position as the suppliers of prepared land. Needham and Faludi (1999) provide the historical context behind this assumption:

There had been so much experience with this development process; it had worked so well that it had become taken for granted. And even though [with VINEX] the government introduced as part of its growth management strategy some changes in the conditions under which housing development would take place, insufficient attention was given to the possibility that those changes might influence the markets for land and development (489).

Dutch spatial planners have since dubbed this assumption "the great miscalculation." While developing the compact city strategy, VROM planners had begun discussing location priorities for new development as early as 1990, when the first draft of the VINEX report was circulated. Because land speculation had been virtually nonexistent 
in recent history, planners discussed potential development locations openly and waited until financing had been secured to initiate land purchases. ${ }^{12}$ However, "when the municipalities involved were ready to start acquiring the unserviced land, as was their wont, they discovered to their surprise that the farmers from whom they wanted to buy had often sold the land just recently." (Needham 1997, 294).

VROM's great miscalculation was to intentionally increase the profitability of land preparation, expecting the additional surplus to go to municipal governments without considering potential competition from private developers. However, the combination of land supply limitations and the shift to private housing development had driven up the cost of urbanizable land to a point where potential profits from land development outweighed the financial risks involved (Needham 2007, 193). "Whereas [land preparation] had, for decades, been commercially unattractive, it had suddenly become attractive. Developers had seen their chance, and had acquired land in advance" (Needham 1997, 294).

In this way, VINEX ushered in a new era of speculative development and significantly altered the balance of power between municipal governments and private developers. For planners, this was an extremely unwelcome development: "It gives to the municipality fewer possibilities for influencing the composition, phasing and layout of housing development, it reduces the possibilities that municipalities have of steering [development] through prices and financial flows, and it makes it much more difficult for municipalities to use development gains on land for improving the quality of residential areas" (Needham and Faludi 1999, 489). 


\section{Section III Summary}

The recession of the 1980s prompted a wholesale reexamination of the Dutch welfare state and destabilized the strategic alliance underpinning traditional growth management. By the early 1990s, it was clear that the marriage between spatial planning and social housing had dissolved. The golden strings connecting social housing associations to the national government had been cut, and the newly privatized associations would be responsible for their own financial risks. For spatial planners, the traditional mission of providing adequate land and infrastructure for development had been abandoned in favor of a new priority: the concentration of development in and around existing urban areas. Under VINEX policy, environmental concerns trumped all other planning objectives, lending new urgency to the tasks of preserving open space and reducing automobility (Priemus 1998).

Thus, new development under VINEX would be highly concentrated, and would be dominated by private developers building for homeownership rather than housing associations building for renters. In accordance with VROM's objectives for these concentration policies, a significant "value increment" has since developed between protected agricultural land and greenfield sites available for development (Korthals Altes 2008, 12). Barrie Needham estimates that, all else being equal, urbanizable greenfield land in the Netherlands now commands a price ten times higher than agricultural land protected from development (personal communication, Barrie Needham, March 13, 2008). In the following section, I will explore the implications of these shifts in Dutch growth management policy with respect to the problem framework introduced above. 


\section{SECTION IV: INTERVIEW FINDINGS}

\section{Assessing Growth Management in the VINEX Era}

Although VROM published a Fifth National Spatial Strategy in the year 2000, implementation has been slow, and planning in the Netherlands is arguably still in the midst of the VINEX era. Under the original VINEX report, development of the "compact city" expansion areas was slated to commence in 1995 and to conclude in 2005. However, development started significantly behind schedule, and the timeline for these projects has since been extended to the year 2010. As the implementation of VINEX policy continues, analysts are busy comparing initial objectives to the results taking shape on the ground.

Based on an analysis of land use change in the Green Heart and the Randstad during the VINEX era, it would appear that growth management policies have been largely successful in at least one respect: the protection of open space. By comparing satellite imagery sensitive to land use changes during the period spanning 1995-2004, Koomen et al (2008) determine that "in the Green Heart, as well as the Buffer zones, the rate of urbanization has been much lower than in non-restrictive areas." The significance of this finding is heightened "when we realize that these areas are under a higher than average urbanization pressure" (371). The authors attribute these results to the rigidity and clarity of VROM's restrictive zoning policies (374). Although it its too early for a definitive analysis of VINEX policies, these initial findings suggest that the newly "hardened" boundary surrounding the Green Heart and strict limitations on rural development have been effective tools of growth management. 
The effects of VINEX policy on the development process are much less clearcut. It is safe to say, however, that the distribution of economic and political influence amongst stakeholders in the development process has changed significantly in the past two decades (RPB 2008, 2). Compared to the ministry that steered the "bundled deconcentration" process by distributing subsidies to municipalities, VROM today finds itself with much less ability to influence urbanization through stimulative planning. For municipalities, the reduction of national influence via the "golden strings" of governance is a mixed blessing, as increased political independence is coupled with increased financial risk (Korthals Altes 2007). Private developers and social housing associations are both stronger today than they were twenty years ago. The "great miscalculation" of the early VINEX years gave rise to a large private development sector that competes with municipalities and speculates on future urbanization by acquiring and servicing greenfield land. While some of the larger and wealthier municipal governments were able to maintain their local dominance by quickly acquiring greenfield land in the mid-1990s, many smaller municipalities find themselves effectively surrounded by private landholders looking to maximize their involvement in future development. For their part, social housing associations find themselves asset-rich with a great degree of operating freedom and a major role to play in urban redevelopment (personal communication, Maarten Georgius, March 4, 2008).

In the political sphere surrounding spatial planning and development, the issue of stagnant housing production has recently emerged as a major subject of concern. 
While demand for new units has surged during the VINEX era, the rate of housing production has dropped to less than half the historic norms of the postwar period (Korthals Altes 2008, 12). Although many are strategically well-positioned in the market, private and social housing developers have failed to keep pace with the surge in demand. As prices for ownership housing have skyrocketed, analysts have begun searching for the root causes of the housing shortfall. A recent report commissioned by VROM identified some 80 factors contributing to the problem of stagnant production (Taskforce Woningbouwproductie, 2002). Some analysts primarily attribute stagnation to a lack of available building sites, while others emphasize an overabundance of procedural regulations or strategic rationing by dominant market players.

To help make sense of Dutch growth management in the VINEX era, I will turn now to a discussion of my interview findings. This section will proceed thematically, addressing the subjects of land cost, housing cost, development density, and housing affordability. In this discussion, I will address the research questions underpinning my interviews without adhering rigidly to the framework presented in Section I. 


\section{A Scarcity of Buildable Land}

"There is, more or less, agreement that there is a scarcity of building land, for better or for worse. [...] That is the situation in this country. [...] Where there's not agreement is whether [that scarcity] is a good thing or a bad thing, and what should be done about it."

-Barrie Needham, (personal communication, March 13, 2008)

Amongst the group of Dutch planning and housing experts that I interviewed, there was general agreement that land available for development is scarce and relatively expensive throughout the Randstad, and in other high-demand areas of the Netherlands. Multiple interview subjects referenced the "value increment" between agricultural and urbanizable greenfield land as evidence of that scarcity. In 2008, researchers at the national government's Institute for Spatial Research (Ruimtelijk Planbureau, or RPB) found that agricultural land slated for future urban development commanded a price eight times higher, on average, than similar land under permanent agricultural protection (RPB 2008, 3). This is roughly consistent with Barrie Needham's 2008 estimate of a ten-fold increase in average land values associated with permission to develop urban functions (personal communication, Barrie Needham, March 13, 2008). Furthermore, Needham and the RPB analysts concur regarding the existence of significant regional variations within the Netherlands, noting that in highdemand locations (e.g. at the borders of the Randstad), the value increment is significantly higher. 
According to multiple interview subjects, there was little talk of value increments in the Netherlands prior to the introduction of VINEX policy. However, in the past 10-15 years, as a shortage of building land has become apparent, the value increment has become a subject of significant discussion and debate in academic and policy communities (personal communications, Barrie Needham, March 13, 2008; Willem Korthals Altes, April 15, 2008; Willem van der Post, April 23, 2008). Much of this discourse focuses on the economic effects of land scarcity. According to Willem Korthals Altes, a scholar of spatial planning and economics, "The debate today [regarding land scarcity] is different from fifteen, twenty years ago, when there was no such debate. Because [at that time], there was much more balance between what you call negative planning, and more positive planning about facilitating growth in places where you want growth to be happening." Recently, however, "There's much more debate about, 'Is the planning system hindering growth? Is there enough space in the plans for development?' [...] That debate is much stronger now in the last, say, ten years" (personal communication, Willem Korthals Altes, April 15, 2008).

\section{Stagnant Housing Production}

The issue of land scarcity in the Netherlands has, in recent years, been compounded by a shortfall of new housing production. According to policies introduced in VINEX and updated in the report known as "What People Want, Where People Live" (Remkes 2001), housing the growing Dutch population between the

years of 1995 and 2010 would require the production of approximately 100,000 new 
units each year (Boelhouwer 2005, 368). However, actual construction has fallen far short of these targets, peaking at around 80,000 units in the late 1990s before falling to 60,000 in 2003 . This figure represents the lowest level of housing production since 1952 (Boelhouwer et al 2006) and a drop of 35\% from 1995 levels (Boelhouwer 2005, $365)$.

The same period saw an increase in real income in the Netherlands and a decrease in interest rates, leading to a spike in purchasing power and demand for new housing (Rouwendal et al 2004, 10). The combination of anemic housing production and strong demand has lead, not surprisingly, to a surge in housing prices. Over the period 1995-2003, average house prices rose 59\% in real terms (Boelhouwer 2005, $365)$. 
FIGURE 4: Housing Price and Production, 1965-2002

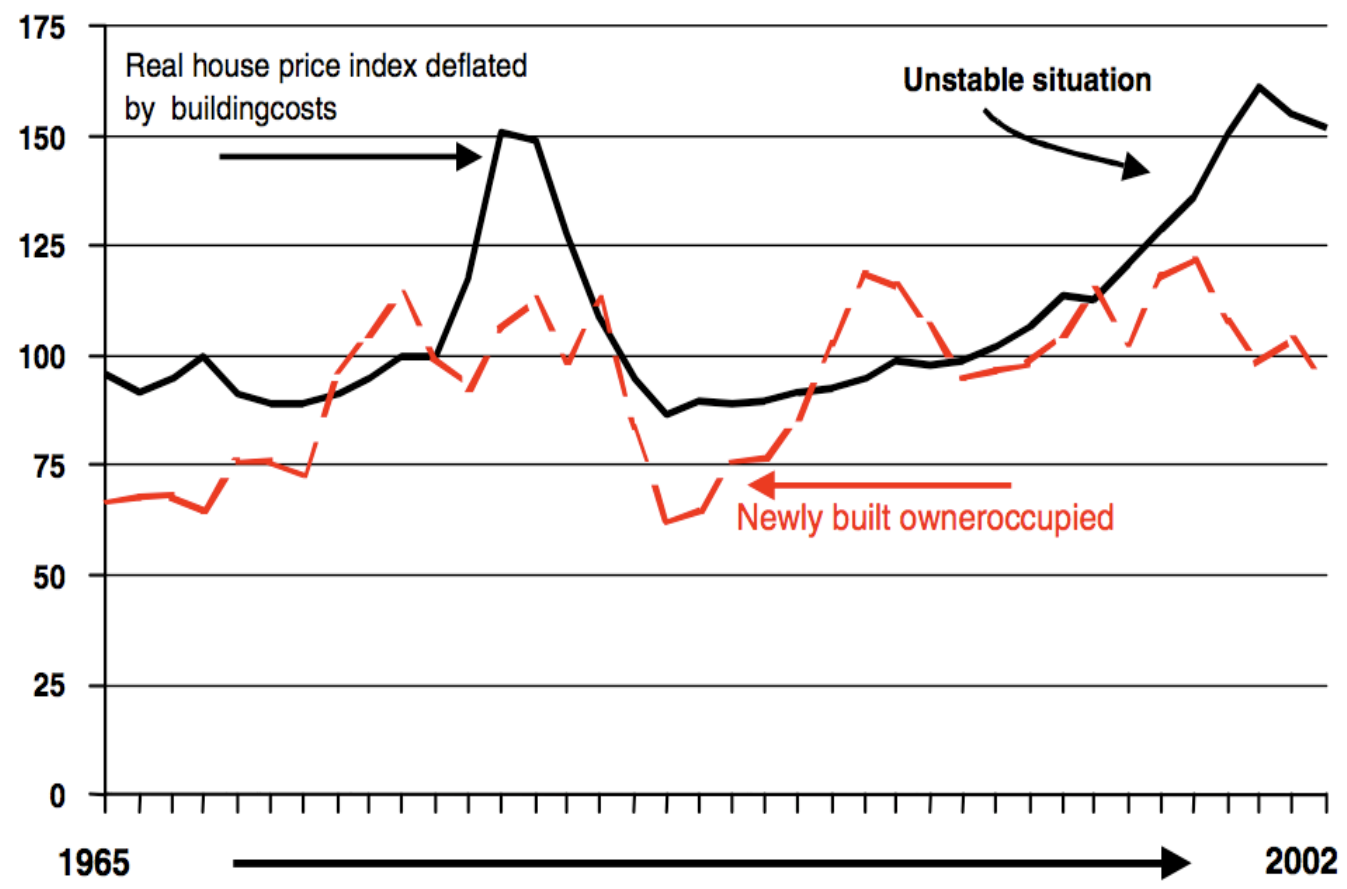

Price (black line) and production (red line) of owner-occupied housing in the Netherlands, 1965-2002. Source: Boelhouwer 2005, 365.

Given the mismatch between housing demand and the production of new units, the elasticity of housing supply is thought to be exceptionally low in the Netherlands. According to a number of the economists I interviewed, the response of private housing producers to price increases is, for all practical purposes, negligible. This anecdotal evidence has been confirmed by researchers at the national government's Bureau of Economic Policy Analysis (Centraal Planbureau, or CPB). Using a variety of complementary analytic methods to estimate elasticity, CPB's Wouter Vermeulen and Jan Rouwendal (2007) find an average .04\% increase in owner-occupier housing construction in response to a $1 \%$ price increase in the same year, leading to the 
conclusion that "housing supply in the Netherlands is almost fully inelastic in the short-run." (43). This finding raises many questions about the availability of input factors to the development process (e.g. land, building rights, construction materials, and labor), as well as the behavior of housing suppliers.

At the time of VINEX publication, VROM analysts expected the years from 1995-2010 to be characterized by strong economic growth and rising demand for owner-occupied homes, bringing the annual target of 100,000 new units easily within reach (Boelhouwer et al 2006, 301). In reality, economic growth and consumer demand exceeded expectations, while housing production fell far short of VROM's targets. As a result, the issue of housing stagnation has been high on the agenda of economists, planners, and policymakers since the beginning of the new millennium, bringing back memories of the country's postwar housing shortage. According to Boelhouwer et al (2006), "Parliamentarians are racking their brains, trying to think up new ways in which the government can kick-start the flagging engine of the housing production. With large parts of the housing policy decentralized, simple solutions are not just around the corner. The renewed spotlight on the housing shortage has taken everyone more or less by surprise" (301).

\section{Causes of Housing Stagnation}

As they ponder rising housing prices and flagging production figures, the question on the minds of analysts is: Why haven't private housing developers responded to price increases by building more new units? Perhaps not surprisingly, 
there are a wide variety of proposed answers to this question. In 2002, VROM commissioned a task force to determine the principal causes of the stagnation problem (Taskforce Woningbouwproductie, 2002). When the report came back, the task force had identified some 80 factors as significant contributors to the housing shortfall (personal communication, Dick Schuiling, May 19, 2008).

When discussing the root causes of housing stagnation, many interview respondents identified a combination of disparate explanatory variables. However, over the course of many interviews, patterns began to emerge in subjects' responses, providing the outlines of three distinct perspectives on the issue of housing stagnation. I will present these three perspectives by discussing key interviews with representative individuals. First, there were those analysts who emphasized a shortage of land available for housing development in high-demand areas. Second, there were analysts who focused on the procedural "red tape" that slows and complicates the processes of planning and development. The third group of analysts referred to "organized scarcity," or the strategic rationing of housing production by powerful market actors, as the primary cause of housing stagnation.

\section{Land Availability}

Gusta Renes, an economist at the national government's Institute for Spatial Research (Ruimtelijk Planbureau, or RPB), was the clearest advocate for the first perspective, emphasizing issues of land supply above other explanations for housing stagnation. In 2006, the national government's Ministry of Finance requested an 
analysis of national spatial planning and its effects on housing prices in the owneroccupied sector. To fulfill this request, Renes and a team of RPB researchers used national government databases to analyze variations in land value and housing production across the Netherlands. During our interview, Ms. Renes summarized the team's findings regarding ownership housing in the private sector:

"When house prices increase, builders will be interested to make a profit, and they will supply new housing. But you have to have land available. And generally, in the Netherlands, what we found is that the regional differences in the availability of land is enormous. When we compare where we build houses and where the price increases were highest, they do not coincide. So we have huge price increases in, for instance, Amsterdam. But we built houses in Amersfoort [a town $50 \mathrm{~km}$ east of Amsterdam]" (personal communication, Gusta Renes, April 28, 2008).

Analyzing national land and housing market data, the RPB analysts found a pattern of constrained development in high-demand urban areas (e.g. the Randstad) matched with an oversupply of buildable land in farther-flung communities, especially in the north of the country. According to this analysis, the national supply of buildable land cannot be said to constrain new housing development. However, in high-demand urban areas, land supply was found to be insufficient to meet demands for new housing (Renes et al 2006). According to Renes, the root of this problem is VROM's method of planning for housing development according to a national spatial strategy, with little or no regard for market signals. Rather than recognizing high home prices as 
"revealed preferences" for a specific location, says Renes, VROM planners tend to view prices merely as a reflection of income and interest rates. Thus, they fail to provide housing in locations where it is most needed according to market preferences (personal communication, Gusta Renes, April 28, 2008).

For Renes and the RPB researchers, these findings are significant primarily because of their implications for national economic growth. The Randstad is the economic hub of the Netherlands, and thus the site of dense business, service, and industrial districts. Using Amsterdam as an example, Renes emphasized the importance of productivity gains realized in these districts:

"We have a lot of economic growth in Amsterdam, and productivity is high in Amsterdam because a lot of firms get together there. And you have knowledge spillovers and [other] agglomeration economies. [...] And if you are not able to build houses in these areas, that will cost you a lot of economic growth. Because [employment will re-locate] to Almere, or Amersfoort, or wherever. And it will be less productive there, because there are not a lot of firms available to work with, for spillovers, or [other forms of agglomeration]. [...] That means that if you are containing the land in economic growth areas, you will restrict economic growth, as well” (personal communication, Gusta Renes, April 28, 2008). In addition to impacting firms' capacity for economic productivity, the RPB team found that national spatial planning has a negative impact on housing affordability. While lower interest rates and higher incomes have offset national home price increases for many buyers, Renes et al (2006) found that a problem of access to home 
ownership does exist in high-demand regions, especially for first-time buyers and lower-middle income households. "These buyers must take out relatively high mortgages and must build [up] significant capital if they are to eventually [pay off] the mortgage. [...] This can be a particular problem for low-income households and young families, who in many cases will be accumulating negative equity" (Renes et al 2006, 3). Based on their findings of disproportionately high land rents in these same highdemand areas, the RPB researchers suggest that the lack of suitable development sites in preferred areas contributes significantly to the problem of limited housing access.

When discussing the causes of housing supply stagnation, a number of other interview subjects echoed the RPB team's emphasis on land supply constraints. In particular, respondents tended to emphasize the failure (or refusal) of national planners to respond to housing market signals. Instead of developing the most desirable areas first, planners channel housing to locations deemed "spatially appropriate." The result, according to these respondents, is an over-supply of land in the least desirable areas of the country, while the number of parcels suitable for development within the Randstad dwindles.

Interview respondents closely associated with the development sector noted the increasing difficulty of development within Amsterdam and other high-demand Randstad cities. By 2008, after more than a decade of concentration policy under VINEX, most desirable infill sites had been developed, leaving only the most challenging (and most expensive) sites to accommodate future development within the built-up area of the Randstad (personal communication, Marten Georgius, March 4, 
2008; Ralph Ploeger, April 22, 2008). As a result, the development process is becoming increasingly expensive, labor-intensive, and slow.

\section{Red Tape and Development Delays}

In its report on the causes of housing stagnation, the national government's Housing Production Task Force (Taskforce Woningbouwproductie, 2002) focused on three principal factors: a) multiplicity, complexity, lack of transparency and discretionary changes in policies and rules governing development; b) excessive local government planning procedures; and c) insufficient personnel in public and private organizations involved in planning and development (Korthals Altes 2006, 108). A number of interview respondents referenced these findings directly when discussing the problem of housing stagnation. For some analysts, the task force report seems to have confirmed suspicions that the development process is being held up by a combination of excessive red tape and a culture of planning via negotiation, which demands significant human resource expenditure and injects uncertainty into the development process.

Willem Korthals Altes is a planning scholar at Delft Technical University focused primarily on the economic dimensions of Dutch spatial planning and housing policies, and a proponent of one variation on the "red tape explanation" for housing stagnation. According to Korthals Altes, much of the stagnation problem can be explained by the expanded role of provincial spatial plans as "integrators" of disparate policy objectives (Korthals Altes and Groetelaers 2007). While provincial 
governments have always had the power to review and deny municipal land use plans, the past decade has seen a significant growth in the quantity and complexity of development conditions imposed by provincial planners (Korthals Altes and Groetelaers 2007, 7). Thus, municipal planners seeking provincial approval of local development plans must now face an expanded list of requirements for plan approval. Depending on the province, those requirements may include proof of compliance with all applicable national and EU environmental laws, as well as statements pertaining to geological factors, soil quality and chemistry, site heritage, and archaeological factors (Korthals Altes and Groetelaers 2007, 7). An oversight in any one of these areas can bring the permitting process to a halt, forcing developers and planners back to square one. Citing his own recent research into the subject, Willem Korthals Altes estimated that only $50 \%$ of all municipal development plans are approved outright by provincial authorities, while $10 \%$ are rejected and $40 \%$ are given provisional approval, thus requiring additional due diligence work and prolonging the approval procedure (personal communication, April 15, 2008).

The problem of arduous permitting procedures is heightened by the third factor presented by the Housing Production Task Force: insufficient planning and development personnel. For much of the past decade, unemployment in the Netherlands has been extremely low, leaving vacant many key positions in municipal and provincial government, and in development firms responsible for housing production (personal communication, Korthals Altes, April 15, 2008). This is especially true in smaller jurisdictions, where limited planning staffs are frequently 
overwhelmed by the number of development plans requiring review (personal communication, Dick Schuiling, May 19, 2008). In response to a question regarding the supply of land available for development, University of Amsterdam housing scholar Dick Schuiling mused, "Would it help if we had twice as much new [housing] locations? Well, some say yes. Others say: we [would] have the same number of civil servants...to handle all these building applications. So...get in line!"' (personal communication, May 19, 2008).

To summarize, these respondents portrayed housing stagnation as a result of excessive procedural red tape, and a lack of sufficient personnel to cut through that red tape. In an attempt to alleviate stagnation, the national and provincial governments have recently dispatched special "housing boost teams," consisting of civil servants tasked with clearing up procedural blockages and streamlining development negotiations (personal communication, Joline Santen, May 7, 2008). While the efficacy of this form of procedural streamlining has yet to be determined, the response by both national and provincial governments lends some credence to the argument that red tape has significantly restricted timely housing development.

\section{Organized Scarcity}

According to Barrie Needham, there is a good deal of naiveté amongst neoclassical economists regarding the likely effects of land market deregulation in the Netherlands. A common assumption amongst these economists is that land releases would result in rapid new development in large quantities, but Needham points to the 
case of Israel to demonstrate otherwise (personal communication, March 13, 2008). In research published in 1998, Needham and Verhage found that private landowners in Israel were well-positioned to carefully ration development, increasing development profits by maintaining housing scarcity. Thus, in markets where buildable land is scarce, maintaining that scarcity may be in the best interest of dominant market actors (Needham and Verhage, 1998).

A certain amount of this "organized scarcity" already occurs in the Netherlands. As Needham explained to me, "The development industry in this country, the NEPROM - the Netherlands property development society - [...] their members have said: 'obviously, we want to build more houses, but not too many more houses.' Because they've got enormous reserves of land, which is not yet zoned for housing, but that they hope will be zoned for housing, but-slowly. Because they don't want to damage their market" (personal communication, March 13, 2008). For this reason, Needham says, developers in the Netherlands tend not to lobby very hard for land market liberalization, as they prefer to increase the housing stock gradually. In fact, in regions that see consistent housing price appreciation, private developers are known to drag their heels during the development process in an effort to time the market and deliver their products at the highest achievable price point (personal communication, Dick Schuiling, May 19, 2008).

However, because of the unique division of responsibilities in the Dutch development process, private parties are not alone in pursuing a strategy of rationed development. Many of the larger municipal governments maintain a position of 
dominance in their local land market, allowing them to "organize scarcity" and drive up the revenue-generating potential of public land development (personal communication, Gusta Renes, April 28, 2008). A number of interview respondents emphasized these monopolistic tendencies of municipal government, including one planner from the municipality of Amsterdam (personal communication, Koos van Zanen, March 11, 2008). According to Koos van Zanen, the scarcity of buildable land in Amsterdam works to the benefit of both the municipality and private developers (personal communication, March 11, 2008). High land costs allow the municipal department of land development to do its work, capturing revenue needed to support parks, transportation infrastructure, and social housing. Meanwhile, according to van Zanen, land scarcity also maintains a favorable business environment for private land developers:

"We [municipal planners] say what's happening[...]And the interesting thing is that the market stakeholders- they don't feel bad about it. Free market stakeholders, to a certain extent, want to be ruled by a Big Brother. We, as a Big Brother, we make the [land] scarcity. And what's better for the market than scarcity? [...] If we keep[...]the scarcity up[...]the market stakeholders [can make] the most profit of it. It [may seem] the other way around-that by having space, you can do what you want and make money. But we say, 'by having no space, you can also make money.' [...] And I think it's the truth" (personal communication, Koos van Zanen, March 11, 2008). According to a number of interview subjects, this strategy of organizing scarcity - 
practiced by private and public landowners alike — is the primary cause of stagnant housing production.

\section{Density of Development}

In the problem framework that guides this research, I state "planners and policymakers may be able to stem housing price inflation by allowing or encouraging significant density increases within the area available for development." This statement is based on the notion of a "density offset," a theory rooted in classical urban economics that is often advanced by proponents of growth management. According to the classical economic theory of factor substitution, housing producers tend to respond to higher land costs by reducing lot sizes and shifting development to housing types that consume less land per unit. ${ }^{13}$ As noted in Section I, this theory has prompted planners and policymakers in the United States to incorporate tools promoting density increases into some growth management policies in a bid to mitigate land price increases.

During the interviews I conducted in the Netherlands, I asked respondents a variety of questions related to the "density offset" theory. Namely, I attempted to discover whether Dutch housing producers tend to increase development densities in response to land cost increases. Furthermore, I wanted to know whether and how planning powers may be used to compel housing density increases.

When discussing the economic relationship between land prices and development density, interview subjects described a far more complex dynamic than 
the classical "factor substitution" model would suggest. In the Netherlands, as in the United States, the relationship between land and housing markets is mediated by land use law, which places conditions on the right to develop. Those conditions may include matters such as the function, form, density, and type of development. However, in the Netherlands, such conditions are often not codified in zoning plans covering large areas. Rather, municipal planners prefer to zone large areas at the globaal (approximate) level, keeping parameters for development as general as possible (Needham 2007, 130-133). Such globaal plans can specify which details remain to be worked out before a building permit can be granted. When development is proposed within the plan area, those details become the subject of negotiations between municipal planners and developers. In this way, a great deal of municipal planning takes place at the level of individual developments, through a process of direct negotiation. By committing only to general land use parameters at the outset of negotiations, municipal planners increase the number of variables up for negotiation and improve their bargaining position relative to developers (personal communication, Barrie Needham, March 13, 2008).

According to Barrie Needham, because of this practice of site-specific planning, "zoning in terms of minimum or maximum density is...not the practice. Because the details—and these would include the details of the density—get worked out, very often, in negotiations. Not within the zoning plan" (personal communication, June 11, 2008). These negotiations can include any and all dimensions of the land use plan, and are bound only by the requirement that nothing can be specified which is not "spatially 
relevant" (Needham 2007, 130). Although I interviewed a number of planners and municipal officials who frequently participate in such negotiations, I was not able to determine how development density interacts with other variables at play in the negotiation phase of municipal planning.

To further complicate matters, in cases of municipal land ownership-which are frequent - the land price may also be subject to negotiation, as planners frequently elect to subsidize certain forms of development through discounted land preparation services. In these cases, the municipality plays multiple roles-land supplier, land developer, and regulator of development — and exercises a large degree of influence over land prices. Because of this concentration of responsibilities in the hands of municipal planners, I was not able to draw any general conclusions regarding a market-based relationship between land price and housing density. Barrie Needham suggested that my confusion on this matter is common to analysts attempting to apply classical economic assumptions to Dutch land use planning and development processes. As Needham put it, the "very confusing division of responsibilities" in the land and housing development process tends to scramble common assumptions about supply and demand relationships, and thus renders many classical economic models useless (personal communication, March 13, 2008). Given the practice of planning via negotiation, Needham suggested that development density is better understood as a product of complex political processes rather than "pure" market forces. A number of other interview respondents echoed this sentiment, describing housing density as a subject of shifting municipal planning priorities, rather than an expression of land 
market dynamics.

\section{The State of Low-Income Housing}

The experts I interviewed expressed significant concern regarding the recent trends of rapid housing appreciation coupled with falling housing production. In voicing their concerns, many respondents spoke in terms of systemic health, arguing that the low elasticity of housing supply signaled a "dysfunctional housing system," or a housing market that is "out of balance." Others, such as Gusta Renes, advanced more pointed critiques couched in terms of economic efficiency. These respondents tended to portray the problem of housing stagnation as a threat to national economic productivity, or as a cause of inefficient side effects such as increased commuting between cities. However, despite the universal recognition of a significant housing shortfall, I heard very little concern for the housing conditions of low-income populations. In general, respondents did not describe housing stagnation as a threat to housing equity.

One potential explanation for this lies in the divorce of the spatial planning and social housing systems. Without a doubt, Dutch planners are far less engaged in promoting housing affordability since the privatization of social housing associations and the end of "bundled deconcentration." It might be argued that spatial planners in the Netherlands no longer see affordability as an issue of their concern. But in actuality, this was not the impression I received from interview subjects. Rather, respondents tended to believe that, in spite of the shortfall in overall housing 
production, low-income households continue to be well served by social housing providers and by the central government's supplementary system of housing allowances. According to respondents, the systemic dysfunction of the housing market is simply not "filtering down" to significantly impact low-income households.

A number of respondents, including two housing experts based in Amsterdam, argued that the major cities of the Randstad currently have an overabundance of housing units targeted to low-income renters. Floris Blom is a senior policy advisor at the municipality of Amsterdam's Department of Housing (Dienst Wonen). According to Blom, organized citizens and elected officials in Amsterdam have consistently lobbied for affordable housing, resulting in a particularly large supply of social housing within the municipality's stock. In the current era, a combination of municipal cross-subsidy programs and direct subsidies from the central government provides ample funding for the municipality's affordable housing programs. Blom told me that, thanks largely to close partnerships with strong social housing developers, organizing sufficient low-income housing production "just isn't that challenging any more" for the municipality. In fact, the capacity of Amsterdam's low-income housing stock significantly exceeds the size of the low-income population it is meant to serve (personal communication, Floris Blom, April 29, 2008).

Dick Schuiling, a housing expert at the University of Amsterdam, was careful to point out the exceptional nature of Amsterdam, which is the wealthiest and most politically powerful municipal government in the Netherlands. While municipal planners in Amsterdam continue to operate like "the good old days"- -subsidizing 
social housing development through discounted land preparation—most municipalities in the Netherlands can no longer afford to play such an active role in social housing development. However, Needham also confirmed Floris Blom's more general argument regarding the excess supply of low-cost rental housing in Amsterdam, and in most major cities in the Randstad (personal communication, Dick Schuiling, May 19, 2008). Indeed, on a national scale, social housing constitutes $36 \%$ of the housing stock, while just $28 \%$ of Dutch households fall into the social sector's target income group (Milligan et al 2006, 241). ${ }^{14}$

According to Floris Blom, Amsterdam's continued success in providing adequate affordable housing is due, in large part, to the financial strength of the social housing sector. In times when municipal budgets are tight and affordable housing production is threatened, social housing associations are generally willing and able to increase their own capital investments to keep construction on track (personal communication, Floris Blom, April 29, 2008.) This perception—of social housing associations flush with available capital—was common amongst interview respondents, and not without reason. Value estimates of the social housing sector's collective holdings range from 22 to 24 billion Euros - figures which speak to the Dutch government's substantial historic investment into social housing (Boelhouwer 2005, 371; Priemus 2003, 330).

Hugo Priemus of the Delft Technical University is generally considered to be the nation's leading expert on housing issues. In a 2003 evaluation of the Dutch social housing sector, Priemus found that, while conditions vary for individual housing 
associations, "the Netherlands social housing sector is on a firm financial footing...No country in Western, Central, or Eastern Europe has professional private housing associations with such large amounts of capital at their disposal" $(338 ; 349)$.

Furthermore, Priemus found that affordable housing providers continued to serve their core function well, providing technically sound and well-maintained housing to vulnerable groups. Thus, "it can be concluded that social housing in the Netherlands is effective in meeting public tasks" (340). The question, for Priemus, is whether such a robust system of affordable housing production is still needed in the Netherlands. "Although the large scale of the social rental sector can be accounted for historically, that is not to say that the current high market share of 37 per cent [of the national housing stock] can be justified. [...] The Netherlands is one of the most prosperous countries in the world and household incomes and capital are rising inexorably. The social rental sector in the Netherlands is actually so differentiated and so attractive, not only do low-income groups live in it, but also middle and higher-income groups" (330).

Echoing Priemus' analysis, the experts I spoke with portrayed the Dutch social housing system as financially sound, politically powerful, and highly competent in providing high-quality housing to low-income households. Furthermore, respondents emphasized the importance of ample support available to vulnerable families in the form of direct aid from the central government. Since discontinuing supply-side subsidies to housing producers, the national government has invested heavily in a means-tested system of rent rebates provided directly to low- and moderate-income 
households. ${ }^{15}$ Between 1984 and 1999, expenditure on these demand-side subsidies increased 170 fold in nominal dollars, so that by 1999 , some $15.5 \%$ of all Dutch households received some form of rent rebate from the national government (Milligan et al 2006, 242). According to Dick Schuiling, approximately $30 \%$ of renters of social housing also receive rent rebates (personal communication, May 19, 2008).

\section{The Gap in the Middle}

Describing the strength of Dutch social housing and rent support does not tell the whole story of housing affordability in the Netherlands. While the majority (54.6\%) of low-income households live in social housing, $12.3 \%$ of such households find housing on the private rental market and $42.1 \%$ opt for home ownership (Milligan et al 2006, 246). In a 2003 assessment of low-income housing in the Netherlands, University of Sydney researcher Vivienne Milligan found that "many low-income households in the Netherlands have reasonable affordability ratios by international standards" (246). However, Milligan et al found significant differences in average housing expenditure according to tenure. While low-income households living in social housing spent a reasonable $26.5 \%$ of disposable income on rent, those living in private-market housing tended to be significantly worse off. Low-income home purchasers (i.e. those with a mortgage) had an average housing expenditure ratio of $36.8 \%$, while low-income households in the private rental sector spent $30.2 \%$ of disposable income on rent (246).

These findings confirm the reports I heard from interview respondents, who 
often spoke of a "gap in the middle" of the Dutch structure of housing support. When asked to identify the most vulnerable groups on the housing market, respondents invariably pointed to lower-middle income households, young families, and starters on the private market. According to my respondents, while the poorest households tend to be particularly well-served by the combination of social housing and rent vouchers, households attempting to move out of social housing and into private home ownership must amass a sizable down payment, which is often beyond their reach. These are the same households of concern for Gusta Renes, who argues that accumulating negative equity is a significant problem for many starters on the private market (Renes et al 2006, 3). According to Dick Schuiling, a problem of housing access has developed in recent years, in which many lower- and lower-middle income households that would prefer to buy a home are forced to remain in social housing. "Because their rents are low and the quality of [social] housing is high, it's hard to call this a problem of strict affordability. But [with] housing choice...housing access? There, we have a problem" (personal communication, Dick Schuiling, May 19, 2008).

\section{Findings Summary}

Amongst the group of Dutch planning and housing experts that I interviewed, there was general agreement that land available for development is scarce and relatively expensive in high-demand areas of the Netherlands. When our discussions turned to the causes and implications of land scarcity, responses tended to be more varied. Many of the experts I spoke with noted that developable land was more readily 
available fifteen to twenty years ago, and a number of respondents characterized land scarcity as an intended effect of growth management policies under VINEX.

Regarding the subject of housing stagnation, the only truly universal sentiment amongst respondents was that the shortfall of housing is an exceedingly complex phenomenon, likely caused by a variety of interactive variables. However, despite the diversity of individual explanations for the phenomenon, I was able to identify three distinct perspectives on housing stagnation: one emphasizing a shortage of building sites due to national spatial planning regulations, another highlighting the combination of red tape and personnel shortfall, and a third focused on oligopolistic behavior of powerful market actors. Given the depth of support for each of these positions, it seems likely that all three explanations have some validity, describing real dimensions of the housing stagnation phenomenon.

My findings were largely inconclusive regarding the relevance of a "density offset" effect as a response to land price increases in the Netherlands. Due to the complex division of labor within the Dutch development process, I was not able to discern any market-based relationship between land prices and housing densities. Barrie Needham suggested that this is a common problem when applying classical economic models to the Dutch development process, and that development density is better understood as a product of policy decisions than of "pure" land- and housingmarket interactions. However, because the majority of those policy decisions take place in the context of site-specific planning negotiations, I was not able to discern much about whether or how the variables of land cost and building density might be 
related.

Finally, I found that respondents tended not to portray the housing shortfall as a threat to housing equity. Respondents asserted that, despite the recent decline in overall housing production, low-income households continue to be well served by social housing providers and by central government housing allowances. Indeed, analyses suggest that the social housing sector is financially sound, politically powerful, and highly competent in providing high-quality housing to low-income households. However, a significant number of lower-middle income families seem to fall into the "gap in the middle" of the Dutch structure of housing support. When asked to identify the most vulnerable groups on the housing market, respondents consistently pointed to lower-middle income households, many of which would prefer to move from the social housing sector into private home ownership. The high cost of private housing often precludes this, suggesting that housing choice and accessibility may be limited for some groups in the Netherlands, even if housing quality and affordability are reasonable by international standards. 


\section{SECTION V: DISCUSSION OF FINDINGS}

\section{Broad Support for Growth Management}

"There is a great consensus-a remarkable political consensus-in this country, that land use planning is useful. And the radical critiques [of planning] which you find...in the States, and to some extent in England, are just absent here."

—Barrie Needham (personal communication, June 11, 2008)

In the United States and the UK, the neoclassical critique of growth management policy has often been cited as justification for the deregulation of land and housing markets. Based on the argument that such regulations drive up land and housing costs, campaigns against regulatory growth management have taken up the banner of preserving affordable housing opportunities. At times, economists themselves have joined these efforts, arguing that housing markets can be improved in terms of both efficiency and equity by reducing regulatory barriers and increasing consumer choice with regard to the location, type, and price of housing.

Amongst the Dutch experts that I interviewed, I found widespread agreement regarding the high cost of land available for development in the Netherlands. Most respondents believed that national spatial planning policies make buildable land more expensive, and a number of respondents argued that such policies reduce consumer choice and create barriers to home ownership for certain segments of the market. In this way, respondents shared many of the same concerns as neoclassical critics of growth management. However, calls for broad-scale deregulation of the land and 
housing markets were notably absent from the discussions I had with Dutch planners, economists, and housing experts. Instead, I heard widespread support for the fundamental objectives of growth management and select arguments for limited policy reform.

\section{The Planning Perspective}

During interviews with practicing planners and scholars of Dutch spatial planning, I was struck by repeated assertions of universal support for open space preservation policies. Time and again, I was told that "everyone agrees" regarding the importance of protecting the Green Heart and containing urban development. According to a number of respondents, this base of support extends far beyond the community of spatial planners, and includes private stakeholders and small municipalities with ambitions to grow. Maarten Nip, a regional planner with the Amsterdam Metropolitan Area, explained the consensus regarding open space preservation in terms of broader societal values: "It's deeply rooted in the culture. It's not so much consensus between different political parties-[where] one party wants that and the other one something else, and then they agree-no it's really a deeperrooted, and very important [idea]...[Dutch city-dwellers] feel it's very important that it's possible to go on bike, and in twenty minutes, you're in a green area" (personal communication, Maarten Nip, May 21, 2008).

While I was unable to independently verify the support for open space preservation amongst all relevant stakeholder groups, I came away from my 
interviews convinced that the objective of Green Heart preservation is alive and well in the Netherlands. It would seem that planners, in particular, continue to strongly support the "doctrine" of open space preservation promulgated by VROM, as described by Faludi and van der Valk (1994). However, I also found planners to be strikingly open regarding the costs and consequences associated with preserving the Green Heart. In particular, planners tended to quickly acknowledge the inflationary effect of national open space preservation on land prices. And, while some argued that the issue of housing shortage is a perennial problem in the Netherlands-a fact of life in a nation with limited dry land and a growing population-a number of planners asserted a direct connection between the recent housing shortfall and the strictures of the spatial planning system.

Amongst these respondents, the problem of housing stagnation was seen as an unintended consequence of national spatial planning; a policy outcome that decision makers can and should influence through policy reform. In the meantime, these respondents tended to be extremely supportive of, and grateful for, the existence of the social housing system and the national government's demand-side housing assistance. It seems that these systems function as a vital safety net, not only for the households they serve, but also for planners and policymakers shaping land and housing development. Because the social housing system continues to provide high-quality housing at reasonable rents, planners and policy makers are able to pursue ambitious spatial and environmental objectives, secure in the knowledge that vulnerable populations will be largely shielded from any unintended policy consequences. 
On the whole, then, the perspective of planning professionals seemed to be that growth management policies reflect deep and widely held values attached to open space and the preservation of agricultural and natural areas. Planners tended to acknowledge that these policies come at a cost, specifically in the form of land value inflation and, for some, housing price increases. Rather than undermining support for growth management, these costs were regarded pragmatically, as the subjects of needed policy reform. Finally, planners took pains to point out the efficacy of various forms of housing support, which prevent vulnerable populations from bearing the unintended costs of growth management.

\section{An Alternative Economic Perspective}

After a handful of interviews with Dutch economists and planners, I began to notice an interesting pattern. When discussing the interaction between land and housing markets, respondents tended to reverse the direction of causation that I was accustomed to. That is, instead of treating land cost as an independent variable with significant impact on average housing costs, respondents tended to portray land costs as a function of housing market dynamics. In fact, on more than one occasion, an interview subject paused to correct my mistaken understanding of Dutch market dynamics. During my first formal interview, VROM policy analyst Arjen van der Burg stated simply: "the point is not, in itself, that [...] say, concentration policies or restrictive policies, drive up land prices. They drive up housing prices. [...] The level of housing prices is very high in most areas. And that makes land also expensive" 
(personal communication, February 28, 2008).

My own understanding of housing markets was based primarily on neoclassical studies from the American and British literatures on planning and economics. These studies tended to assume open and competitive markets, and often emphasized the effects of supply-side variables on average housing prices. Such supply-side variables include the price of land, construction costs, and credit conditions. In many neoclassical analyses of land use planning, particularly in the US literature, construction costs and credit conditions are held constant, bringing land costs into focus as a primary determinant of home prices. ${ }^{16}$ Boelhouwer (2005) nicely summarizes this perspective:

The [mainstream neoclassical] approach sees the housing market as differing little from other markets, where prices are determined mainly by supply and demand. [...] It is implicitly assumed here that the housing market operates as a supply market. [...] The idea behind this supply-directed approach is that in the long term the price of newly built housing follows the production costs. The factors that determine the costs of new building (including land and construction costs) mark the starting point for a new price equilibrium. We find this pattern most clearly in the United States, where various researchers have demonstrated a strong relationship between trends in building costs and house prices." (367) This emphasis on building costs is evident in the problem framework that guides this research, in which I state, "by increasing the cost of land, regulatory growth management policies may significantly increase average housing costs." By contrast, 
the Dutch economists I interviewed tended to emphasize the market dynamics within the existing housing stock when discussing average housing prices. According to this perspective, land costs follow broader housing market dynamics, and are generally assumed to have little or no independent impact on average housing costs (personal communication, Arjen van der Burg, February 28, 2008).

Upon researching this issue further, I discovered a much broader trend amongst Dutch economists and planners: a frequent objection to neoclassical explanations for Dutch land and housing market dynamics. According to a number of economists, neoclassical models are simply a poor fit for the highly regulated land and housing markets of the Netherlands (Rouwendal et al, 2004; Vermeulen and Rouwendal 2007; Boelhouwer, 2005; Boelhouwer et al 2006; Needham and Verhage 1998; Needham 1992). Because municipal governments have traditionally played a dominant role in supplying buildable land in the Netherlands, land supply is best understood as a policy outcome, rather than a product of open market transactions (Needham and Verhage 1998). A similar argument has been made with regard to the limitations on developable land imposed by national planning directives (personal communication, Gusta Renes, April 28, 2008). "In this system, the supply of residential land is indeed a government affair, and market signals can have effects only to the extent that government institutions are sensitive to them" (Vermeulen and Rouwendal 2007, 20). Thus, the assumption of open and competitive land markets, which underpins classical urban economics, is extremely problematic in the Netherlands.

In place of classical assumptions regarding open markets, Dutch economists tend 
to focus on the policy decisions that influence land and housing supplies. In a 1992 article, Barrie Needham developed a theory of land price dynamics in markets where land is supplied publicly. Focusing on the effects of land use law and planning practice, Needham states: "It is apparent that whenever the supply of building land is dominated by municipalities, political decisions have an important effect on land prices. They affect both the upper and lower limits of the range within which land prices can be expected to fall... and the actual position within the range" (675). Needham goes on to identify six specific political variables with significant impact on land prices. In addition to decisions regarding the amount of buildable land supplied, these key political variables include the content and application of compulsory purchase law (i.e. powers of eminent domain); the possibility of subsidizing the land development process; the chosen mix of land uses in the plan area; the quality of land servicing; and the possibility of selling prepared land at a discount (Needham 1992, 675-77).

In the years since Needham's article was published, much has changed in the Netherlands, particularly with regard to the relative market influence of municipal governments and private land developers. It might be argued that the growth of private land development has moved the Netherlands away from Needham's model of public land supply, and toward the type of open and competitive land market assumed by classical economists. When asked whether the developments of the past decade had fundamentally changed the nature of Dutch land and housing markets in this way, Gusta Renes acknowledged the growing influence of private stakeholders over the 
content of spatial plans in certain regional markets. However, Renes argued, when seen from an international perspective, "the influence of the [national] government on numbers and prices and quality [of houses] is still very, very high [in the Netherlands]" (personal communication, April 28, 2008). Renes went on to argue that the national government's spatial planning system continues to set the parameters of land development in terms of both quantity and location: while the VINEX years have seen greater participation by private land developers, the borders of the Green Heart have been maintained, and new urbanization has largely followed VROM's national spatial plans (personal communication, April 28, 2008). Other contemporary Dutch economists would seem to agree with Renes, recognizing a rise in private development activity while continuing to view national land supply as a policy outcome (Rouwendal et al, 2004; Vermeulen and Rouwendal 2007; Boelhouwer, 2005; Boelhouwer et al 2006).

It is important to note that this emphasis on policy decisions does not imply a total rejection of market forces. Rather, in the case of housing, Dutch economists seem to prefer a model in which market forces are expressed through a process of stock adjustment (Needham and Verhage 1998, Boelhouwer 2005, Boelhouwer et al 2006, Renes et al 2006). At the core of this theory stands the notion that markets for durable goods (e.g., housing) must be modeled differently than markets for non-durables, in which prices are dominated by supply of, and demand for, new products (Needham and Verhage 1998, 35). When applied to housing markets, the stock adjustment model highlights the proportionally large stock of existing housing. Ultimately, it is argued, 
the dynamics within the market for existing housing have a far greater influence on average housing prices than does the supply of new units (personal communication, Barrie Needham, March 13, 2008; Boelhouwer 2005, 367). For this reason, it makes little sense to treat land supply and construction costs as significant determinants of average housing costs. According to the stock adjustment model, "often the opposite effect occurs, with new home prices following the prices for existing stock, as it is the latter that determine how much scope a builder has to sell a home of a particular quality at an appropriate price" (Boelhouwer 2005, 367).

\section{Applications to the Research Subject}

When early interviews first exposed me to alternative conceptions of the relationship between land and housing markets, the broader implications of these ideas were not immediately clear to me. However, as I discovered more about Dutch critiques of neoclassical models, and about the stock adjustment model for housing markets, I realized that the perspective offered by my interview subjects addressed many of the core issues of my research framework.

From the classical economic perspective, land prices typically reflect a combination of location characteristics and the value of realized and potential land uses (Adams and Watkins 2002, 246). The Dutch economists I encountered were explicit in their rejection of these principles of land valuation, arguing that development locations and land uses are highly influenced by policy decisions in the

Netherlands (see, for example, Vermeulen and Rouwendal 2007, 43-44). As Needham 
has noted, Dutch land policy has been employed "in the service of, and an instrument for, [both] housing and town planning policy" $(1988,48)$. Policy decisions thus set the upper and lower limits of land prices, and often determine land prices directly.

According to my respondents, to the extent that market forces influence land prices, it is the value of the existing housing stock that determines land prices, not the other way around. Taken together, these arguments minimize the determinative impact of the land market on average home prices. By extension, these arguments also undermine the neoclassical critique of growth management policy, which is based on the notion of land price as an independent variable with significant impact on average housing prices.

The perspective offered by my interview subjects is significantly distinct from the mainstream neoclassical treatment of growth management policy. Neoclassical economists tend to favor comparative static models of land and housing markets, contrasting economic outcomes with and without public intervention. Adams and Watkins (2002) summarize the strengths and limitations of this approach when applied to land use planning:

The comparative static model...allows us to theorize the impacts of imposing planning constraints on a previously unfettered market. This provides a useful theoretical guide to the likely distributional effects of planning intervention. However, the empirical research cannot replicate this comparative analysis. The planning system was in place throughout the study periods. As such it is difficult to assess the impact of planning intervention because we cannot do a 'before and 
after' experiment. (256)

Limitations notwithstanding, this theoretical model is common in American economic and planning studies. Often, a pre-existing open market is assumed or stipulated, which is subsequently altered by public intervention, for better or for worse.

For reasons alluded to in the analysis above, this formulation of state-market relations did not have much traction amongst the Dutch planners and economists that I interviewed. Whereas the mainstream neoclassical perspective is based on an autonomous and unfettered land market model, my respondents described Dutch land and housing markets as being defined by policy objectives and the institutional framework of governance. In this way, rather than assuming a pre-existing "natural state" of open market transactions, my respondents placed public actions in advance of market dynamics.

Given the long tradition of municipal land preparation in the Netherlands, perhaps this finding is not so surprising. For centuries, public entities have been active in supplying land for development. Throughout much of the twentieth century, public power over land supply was used to achieve a wide array of policy objectives, including both growth management and housing affordability. Today, VROM continues to set the bounds of the national land market through open space preservation policy. Given this history, it is not surprising that Dutch analysts tend to reject the notion of a pre-existing, unfettered land market, and instead choose to focus on the institutional arrangements which structure market behavior. 


\section{Policy Implications}

In their analysis of housing supply elasticity, Vermeulen and Rouwendal (2007) conclude that the response of Dutch housing producers to price signals is negligible in the short, medium, and long terms (43). The authors contextualize this finding through an overview of major public policies affecting land and housing markets over the course of recent decades: "An important element in these interventions appears to be the regulation of land use, so that the supply of residential land is legally a government decision, rather than a market outcome. Consequently, the [extremely low] supply elasticities estimated in this paper should be interpreted predominantly as a measure for the responsiveness of these institutions to price signals" (44). This concluding statement expresses one version of a common argument advanced by many of the economists I encountered: given the degree of public involvement in land and housing markets, policymakers and other architects of the spatial planning system bear significant responsibility for recent housing stagnation.

For adherents to the stock adjustment model of housing markets, stagnant production can be traced to various forms of systemic constraint. While an efficient stock adjustment process will see the market price of new homes come to reflect production costs, it is possible for systemic constraints to prevent stock adjustment and inflate prices. "That could be constraints on the capacity of the producers of new goods, keeping the flow of supply below the flow of demand, or a few producers restraining supply in their own interest" (Needham and Verhage 1998, 35). In Section IV, I presented the three explanations for housing stagnation offered most frequently 
by interview subjects: limited land availability, red tape and development delays, and organized scarcity. Within the broader literature on Dutch housing production, these factors and a handful of others are widely discussed as important systemic constraints.

Responses to the problem of housing stagnation seek to increase the responsiveness of public institutions to market signals, and to remove sources of systemic constraint on housing production. To this end, specific suggestions for policy reform include regulatory streamlining and the boosting of private and non-profit housing production capacity. Several experts I encountered would like to see an increase in "positive planning" and a return to more active municipal land and housing development. Finally, to bring demand in line with the available housing stock, many experts believed that the national mortgage interest tax deduction should be reduced or abolished in order to minimize its inflationary effect on housing demand. ${ }^{17}$

During my interviews and in my review of the broader literature on housing supply stagnation, calls for broad-scale deregulation of buildable land supply were notably rare. As described above, prohibitive land price was generally not considered to be a significant cause of housing stagnation. Furthermore, the stock adjustment perspective tends to downplay the impact of the marginal increases in new home production that might be realized via land supply deregulation. As a number of interview subjects argued, in a market dominated by the sale of existing homes, marginal additions to the supply of new homes would be unlikely to significantly impact average housing prices (Boelhouwer 2005, 367). Barrie Needham was most explicit in advancing this counter-argument to land release; a course of action which 
he suggested would effectively increase profits for private developers while failing to significantly impact consumers' housing costs (personal communication, March 13, 2008). In support of this position, Needham cited English studies of land release scenarios, which bear out his claims of minimal price impact. In research described as "arguably the most sophisticated and comprehensive attempt to quantify the impacts of the [English] planning system on the housing market," Bramley (1993a; 1993b) found that, in response to a doubling of buildable land supply, average home prices would fall by less than $10 \%$ in the long term (Adams and Watkins 2002, 253). In a final report on Bramley's research, the sponsoring Joseph Rowntree Foundation (1994) concluded, "large land releases are ineffective and environmentally damaging ways to reduce prices" (30). The impact of land releases on average home prices is thought to be limited, in large part, by the tendency for housing producers to "organize scarcity." As discussed in Section IV, landowners and developers have an economic incentive to gradually increase housing supply, maintaining relative scarcity even when developable land is readily available. In this way, landowner behavior mediates the relationship between land supply and housing production, and tendencies toward oligopoly curtail the price impacts of land release.

Of all the experts I interviewed, Gusta Renes and Wouter Vermeulen were most supportive of land market deregulation. For both Renes and Vermeulen, an adequate supply of "properly sited" and readily buildable land parcels is understood as one aspect of housing production capacity. From this perspective, a shortage of available land can reduce production capacity, placing a constraint on the stock adjustment 
process and leading to housing price inflation. Indeed, both Renes and Vermeulen argued that national land use planning constrains housing supply in just this way.

However, in their recommendations for policy reform, Renes and Vermeulen both stopped well short of suggesting that national land use planning ought to be dissolved altogether. For Renes, the key to long-term market stabilization and decreased housing price inflation is to permit and encourage the building of adequate numbers of new housing in the high-demand areas of the Randstad (personal communication, April 28, 2008). This implies a relaxation of both procedural and geographic limitations currently placed on development. In addition to requiring an increase in the ratio of residential to industrial area within built-up areas, Renes believes that some expansion of urbanized areas into currently protected green zones is necessary in high-demand regions. Renes also argued that both housing and employment markets could be significantly improved by boosting investment in intraregional transportation infrastructure, which would allow for more efficient commuting within the regional market (personal communication, April 28, 2008). For his part, Wouter Vermeulen was less explicit in his suggestions for policy reform, but implied that eliminating systemic constraints and significantly increasing housing production would require a combination of increased land availability, increased municipal "positive planning" and development, and regulatory streamlining during the planning and permitting processes (personal communication, June 26, 2008). 


\section{SECTION VI: CONCLUSION}

\section{Research Summary}

This case study explores Dutch spatial planning with reference to the American academic literature on systems of growth management. My initial research objective was to describe the Dutch approach to spatial planning, focusing on issues of developable land supply, development density, and housing affordability. In particular, I hoped to describe Dutch efforts to simultaneously promote housing affordability and compact development, and to highlight any planning practices or policy tools used to coordinate those objectives. With those research objectives in mind, I have explored a single overarching research question: How do planners and policymakers in the Netherlands conceptualize and manage the relationship between land and housing markets, and the effects of that relationship on housing affordability?

During the era of "bundled deconcentration," planners and policymakers at the national and municipal levels of Dutch government balanced stimulative and regulatory approaches to growth management, encouraging new development in strategic growth centers while protecting open space in the Green Heart. By providing urbanizable land in quantities sufficient to meet local demands for new development, planners and policymakers prevented significant inflation of urbanizable land values. In connection with this strategy of land provision, national housing policy was supported through a combination of discounted land preparation services and direct subsidies, fueling the growth of Europe's most extensive social housing sector. In this way, it seems that any negative equity impacts that might have resulted from 
regulatory growth management were sufficiently mitigated via massive investments in affordable housing.

In the climate of fiscal austerity that defined the recession decade of the 1980s, the strategic alliance between social housing and spatial planning dissolved, and the era of "bundled deconcentration" came to an end. Then, in the early 1990s, environmental concerns came to dominate the agenda of national planners, and the provision of land sufficient to meet housing demand ceased to be an objective of spatial planning. VINEX ushered in the "compact city" era of national planning, concentrating development in and around existing city centers while simultaneously "hardening" the boundary of the Green Heart and strengthening growth limitations in rural communities. As a result, a significant value increment developed for the first time in the Netherlands, so that land permitted for urban development now commands a price eight to ten times higher than comparable land located in protected areas.

While the demand for new housing has surged during the VINEX years, housing producers have failed to keep pace. Housing stagnation and the attendant spike in home prices have become issues of significant concern in recent years, and both researchers and policymakers are working to diagnose the problem and offer solutions. While contributing factors abound, the group of experts I interviewed identified three principal causes of housing stagnation: insufficient land availability, red tape and procedural delays during planning and development, and the tendency for producers to organize scarcity in their own economic interest.

Despite their significant concern for these issues, respondents did not portray 
housing stagnation as a threat to housing equity. Instead, they expressed confidence in the national system of housing support, which combines an abundant social housing supply with rent subsidies to provide low- and moderate-income households with affordable, high-quality housing. In this way, Dutch citizens continue to benefit from historic investments in the stock of affordable housing, and from ongoing investments in the system of rent subsidies. However, interview respondents also agreed that housing choice and access are limited for some groups, especially lower-middle income households attempting to move from social housing into home ownership. Because of the practice of site-specific planning via direct negotiations, my attempts to illuminate a generalizable relationship between land values and development densities were inconclusive.

Generally speaking, the experts I interviewed were supportive of the objectives of growth management policy in the Netherlands. Planners portrayed spatial planning as a reflection of widely-shared cultural values and spoke of universal support for open space preservation, while also acknowledging some costs associated with growth management. For their part, the economists I encountered tended to emphasize the dominance of public policy and the institutions of governance over market forces. Because of that dominance, economists generally rejected the application of strict neoclassical models to the highly regulated land and housing markets of the Netherlands. The preferred stock adjustment model of housing markets minimizes the impact of land supply on aggregate housing costs and, by extension, undermines the most common neoclassical critiques of regulatory growth management policy. 
While some respondents criticized the planning system for excessive regulations and procedural hurdles, suggestions for policy reform were generally limited in scope and scale. Calls for broad-scale deregulation of land and housing markets were not common amongst the experts I interviewed.

\section{Reflections and Suggestions for Future Research}

In this case study, I have outlined the historical and geographical context of Dutch spatial planning, describing the evolution of growth management policy since the second world war. Based on findings from interviews with 19 experts in the field, I have described the perspectives of Dutch spatial planners, civil servants, and academics with respect to current issues of growth management, housing development, and housing affordability. I have contextualized the responses of my interview subjects by comparing my findings to the American literature on growth management, identifying areas of overlap and discord between the multiple perspectives presented. I have also highlighted contributions offered by my respondents which struck me as particularly new and interesting, such as the tendency for landowners to organize scarcity, the practice of conceptualizing housing markets using a stock adjustment model, and the economic argument against large-scale land release. Above all, I have attempted to accurately convey the complex and multifaceted accounts I heard when I sat down to interview experts on Dutch spatial planning.

The Netherlands has often been called a "planner's paradise," and with good 
reason. The Dutch system of spatial planning combines strong regulatory approaches, active public development, cross-sectoral negotiations and cooperation, and ambitious urban design. For foreign planners and scholars of urban policy, the result is a research context brimming with complexity, unanswered questions, and enticing examples of an extremely active planning tradition. The primary contribution of this case study is its description of the Dutch planning approach in terms familiar to scholars of American growth management. By focusing on issues of developable land supply, housing supply, and housing affordability, I have examined Dutch approaches to some of the biggest challenges faced by proponents of effective and equitable growth management. The resulting description is not simple, neat, or complete. I hope that, at the very least, it is interesting to scholars of American planning, who might have the opportunity to consider familiar subjects through an intriguing foreign lens.

This research has significant limitations, and leaves a number of important issues unresolved. The description of national policy objectives and broad historical developments offered here does not fully satisfy my original curiosity regarding growth management policy tools and planning approaches employed at the municipal level. Current efforts to combine affordable housing and compact development policies receive scant coverage in this case study. And specific issues of concern, such as the relationship between land cost and development density, are only partially explored. These omissions are due, in part, to a simple lack of the time and expertise needed to effectively gather data on policy efforts occurring at multiple levels of government. Moreover, the Dutch practice of planning through negotiations conducted 
at the level of individual developments presents significant challenges to the researcher aiming to understand policymaking and planning practice at the municipal level.

To confront these challenges, future researchers interested in pursuing the issues discussed here would be wise to consider a focused, "bottom up" approach. In specific, I would suggest beginning with a particular plan or development of interest, and working to gain access to the key stakeholders involved. Depending on the degree of access allowed, the planning, permitting and development processes could then be followed throughout the life of a project, augmented by interviews with central players. This would give the researcher access to the "real work" of Dutch planning via negotiation and collaboration, and would shed light on the institutional and interpersonal relationships that define the process. Informed by this observational research, a broader analysis could then be pursued. 
${ }^{1}$ For maps displaying the basic topography and land use of the Netherlands, see Appendix B.

${ }^{2}$ See Appendix A.

${ }^{3}$ See Anthony 2006, p 123-124, for an elaboration on this criticism. For a discussion of the underlying economic theory, see Fischel 1989 and 2004.

${ }^{4}$ For a review and discussion of variables at the intersection of land and housing markets, see: Adams, Watkins and White, eds. 2005; Adams and Watkins 2002.

${ }^{5}$ The term "urban containment" denotes a subset of growth management policies. According to Nelson and Dawkins (2004), the fundamental purposes of urban containment are: (1) to promote compact and contiguous development patterns that can be efficiently served by public services and (2) to preserve open space, agricultural land, and environmentally sensitive areas that are not currently suitable for urban development (Nelson and Dawkins, 2004). These objectives are central to the policies underlying Dutch growth management (Faludi and van der Valk, 1994).

${ }^{6}$ Case study questions are distinct from interview questions posed directly to subjects. For an example of interview questions, see Appendix B.

${ }^{7}$ For a full discussion of these powers, see Needham 2007, 142-146.

${ }^{8}$ As a portion of total predevelopment costs, the combination of land preparation and primary servicing (i.e. the provision of basic infrastructure) often equals or exceeds the cost of land acquisition. In a study of ten large-scale VINEX locations, the Kolpron research institute (2000) found that land acquisition costs averaged $38 \%$ of predevelopment costs, while land preparation and primary servicing combined averaged $42 \%$ of predevelopment costs (see Priemus and Louw 2002, 130). In the case of smaller developments, which enjoy reduced economies of scale, land preparation and primary servicing can combine to exceed $50 \%$ of total predevelopment costs. For a full description of the land preparation process, see Korthals Altes 2008, 8-9.

${ }^{9}$ Municipal influence over land prices operates within certain legal limits. See: Needham 2007, 185-186.

${ }^{10}$ This assumes a cooperative relationship between national and municipal planning departments, via the intermediary provincial government. For a discussion of the complexities of inter-governmental relations and their effects on spatial planning, see Needham 2007, and Faludi 1994.

${ }^{11}$ For a map of the Randstad, see Appendix E.

${ }^{12}$ In fact, maps circulated with early drafts of the VINEX report displayed future "development directions" in detail (Needham 2007, 193).

${ }^{13}$ Because these shifts often entail more capital-intensive forms of development (e.g. steel structures, elevators, enhanced foundations), capital is substituted for land, hence the term "factor substitution."

${ }^{14}$ It should be noted that much of this oversupply is absorbed by higher-income households living in social housing units. Having gained access to the social housing 
system through means testing, tenants cannot legally be forced out if household income rises above the entry threshold. Thus, a significant portion of the social housing stock is occupied by higher-income households. This is a well-documented and much-discussed feature of the social housing market.

${ }^{15}$ For a detailed description of demand-side subsidies, see Priemus 1998.

${ }^{16}$ For further discussion of these theoretical issues, see Adams et al 2005, 24-25.

${ }^{17}$ For discussions of policy reform, see Boelhouwer 2005, Boelhouwer et al 2006, Renes et al 2006. 


\section{WORKS CITED}

Adams, D., \& Watkins, C. (2002). Greenfields, brownfields \& housing development. Oxford: Blackwell Science.

Adams, D., Watkins, C., \& White, M. (Eds.). (2005). Planning, public policy \& property markets. Oxford: Blackwell Publishing.

AEDES. (2007). Dutch social housing in a nutshell. Hilversum: AEDES: Verening van Woningcoporaties.

Anthony, J. (2006). State growth management and housing prices. Social Science Quarterly, 87(1), 122.

Bengston, D. N., Fletcher, J. O., \& Nelson, K. C. (2004). Public policies for managing urban growth and protecting open space: Policy instruments and lessons learned in the united states. Landscape and Urban Planning, 69, 271.

Blom, F. (April 29, 2008). Personal communication

Boelhouwer, P. J. (2002). Trends in Dutch housing policy and the shifting position of the social rented sector. Urban Studies, 39(2), 219.

Boelhouwer, P. J. (2005). The incomplete privatization of the Dutch housing market: Exploding house prices versus falling house-building output. Journal of Housing and the Built Environment, 20, 363.

Boelhouwer, P. J., Boumeester, H., \& van der Heijden, H. M. H. (2006). Stagnation in Dutch housing production and suggestions for a way forward. Journal of Housing and the Built Environment, 21, 299.

Bramley, G. (1993). The impact of land use planning and tax subsidies on the supply and price of housing in Britain. Urban Studies, 30(1), 5.

Bramley, G. (1993). Land use planning and the housing market in Britain, the impact on housebuilding and house prices. Environment and Planning A, 25, 1021.

Brouwer, J. (2000). Recent research on housing environment in the Netherlands. Tijdschrift Voor Economische En Sociale Geografie, 91(3), 316-321.

Cals, J., Bogaers, P., Samkalden, I., Diepenhorst, I. A., Vondeling, A., Bot, T. H., et al. (1966). Second memorandum on spatial planning. The Hague:

Staatsuitgeverij. 
Dawkins, C., \& Nelson, A. C. (2002). Urban containment policies and housing prices: An international comparison with implications for future research. Land use Policy, 19, 1.

DeGrove, J. M. (Ed.). (1991). Balanced growth: A planning guide for local government. Washington, DC: International City Management Association.

Downs, A. (2004). Growth management and affordable housing: Do they conflict?. Washington, D.C.: Brookings Institution Press.

Ewing, R., Bartholomew, K., \& Winkelman, S. (2008). Growing cooler: The evidence on urban development and climate change. Washington, DC: Urban Land Institute.

Evers, D., Ben-Zadok, E., \& Faludi, A. (2000). The Netherlands and Florida: Two growth management strategies. International Planning Studies, 5(1), 7.

Faludi, A., \& Van der Valk, A. J. (1991). Half a million witnesses: The success (and failure?) of Dutch urbanisation strategy. Built Environment, 17, 43.

Faludi, A. (1992). Dutch growth management: The two faces of success. Landscape and Urban Planning, 22, 93.

Faludi, A. (1994). Coalition building and planning for Dutch growth management: The role of the Randstad concept. Urban Studies, 31(3), 485.

Faludi, A., \& van der Valk, A. (1994). Rule and order: Dutch planning doctrine in the twentieth century. Dordrecht: Kluwer Academic Publishers.

Fischel, W. (1989). Do growth controls matter?: A review of empirical evidence of the effectiveness and efficiency of local government land use regulation. Cambridge, MA: Lincoln Institute of Land Policy.

Fischel, W. A. (2004). Comment. In A. Downs (Ed.), Growth management and affordable housing: Do they conflict? (pp. 158). Washington, DC: Brookings Institution Press.

Georgius, M. (March 4, 2008). Personal communication

Geurs, K. T., \& van Wee, B. (2006). Ex-post evaluation of thirty years of compact urban development in the Netherlands. Urban Studies, 1, 139. 
Howell-Moroney, M. (2007). Studying the effects of the intensity of US state growth management approaches on land development outcomes. Urban Studies, 44(11), 2163.

Joseph Rowntree Foundation. (1994). Inquiry into planning for housing. York: Joseph Rowntree Foundation.

Knaap, G. J. (1985). The price effects of urban growth boundaries in metropolitan Portland, Oregon. Land Economics, 61(1)

Kolpron. (2000). Kostenverhaal in Grondexploitatie op VINEX-Locaties. Rotterdam: Kolpron Consultants.

Koomen, E., Dekkers, J., \& van Dijk, T. (2008). Open-space preservation in the Netherlands: Planning, practice and prospects. Land use Policy, 25, 361.

Korthals Altes, W. K. (2006). Stagnation in housing production: Another success in the Dutch 'planner's paradise'? Environment and Planning B: Planning and Design, 33, 97.

Korthals Altes, W. K. (2007). The impact of abolishing social-housing grants on the compact-city policy of Dutch municipalities. Environment and Planning A, 39, 1497.

Korthals Altes, W. K. (2008). Taxing land for urban containment: Reflections on a Dutch debate. Unpublished manuscript.

Korthals Altes, W. K. (April 15, 2008). Personal communication

Korthals Altes, W. K., \& Groetelaers, D. A. (2007). Planning and stagnation in housing production: A changing context for Dutch provinces. Dortmund: Association of European Schools of Planning.

Milligan, V. R., Dieleman, F. M., \& van Kempen, R. (2006). Impacts of contrasting housing policies on low-income households in Australia and the Netherlands. Journal of Housing and the Built Environment, 21, 237.

Ministry of Housing, Spatial Planning, and the Environment. (2006). National spatial strategy: Creating space for development - summary. The Hague: VROM.

Needham, B. (1988). The Netherlands. In G. Hallett (Ed.), Land and housing policies in Europe and the USA (pp. 49). London: Routledge. 
Needham, B. (1992). A theory of land prices when land is supplied publicly: The case of the Netherlands. Urban Studies, 29(5), 669.

Needham, B. (June 11, 2008). Personal communication

Needham, B. (March 13, 2008). Personal communication

Needham, B. (1998). The effects of land policy: Quantity as well as quality is important. Urban Studies, 35(1), 25-44.

Needham, B. (2007). Dutch land use planning: Planning and managing land use in the Netherlands, the principles and the practice. Den Haag: Sdu Uitgevers.

Needham, B., \& Faludi, A. (1999). Dutch growth management in a changing market. Planning Practice \& Research, 14(4), 481-491.

Nelson, A. C. (1985). Demand, segmentation, and timing effects of an urban growth containment program on urban fringe land values. Urban Studies, 52(2)

Nelson, A. C. (1986). Using land markets to evaluate urban containment programs. Journal of the American Planning Association, Spring

Nelson, A. C., \& Dawkins, C. J. (2004). Urban containment in the united states. Chicago: American Planning Association.

Nelson, A. C., \& Knaap, G. (1992). The regulated landscape: Lessons on state land use planning from Oregon. Cambridge, MA: Lincoln Institute of Land Policy.

Nelson, A. C., Pendall, R., Dawkins, C., \& Knaap, G. (2004). The link between growth management and housing affordability: The academic evidence. In A. Downs (Ed.), Growth management and affordable housing: Do they conflict? (pp. 117). Washington, DC: Brookings Institution Press.

Nip, M. (May 21, 2008). Personal communication

O'Loughlin, J. (1992). Between Stuttgart and Sheffield: Amsterdam in an integrated Europe and a competitive world-economy. Amsterdam: Centrum voor Grootstedelijk Onderzoek.

Pellenbarg, P., \& van Steen, P.J.M. (2005). Housing in the Netherlands: Introduction to the 2005 maps. Tijdschrift Voor Economische En Sociale Geografie, 96(1), 132-134. 
Phillips, J., \& Goodstein, E. (2000). Growth management and housing prices: The case of Portland, Oregon. Contemporary Economic Policy, 18(3)

Ploeger, R. (April 22, 2008). Personal communication

Porter, D. R. (1997). Managing growth in America's communities. Washington DC: Island Press.

Priemus, H. (1998). Contradictions between Dutch housing policy and spatial planning. Tijdschrift Voor Economische En Sociale Geografie, 89(1), 31.

Priemus, H. (2003). Dutch housing associations: Current developments and debates. Housing Studies, 18(3), 327.

Priemus, H., \& Louw, E. (2002). Recovery of land costs: A land policy instrument missing in the Netherlands? European Journal of Housing Policy, 2(2), 127-146.

Remkes, J. (2001). Nota mensen, wensen, wonen. Den Haag: VROM.

Renes, G., Thissen, M., \& Segeren, G. (2006). Summary: Betaalbaarheid van koopwoningen en het ruimtelijk beleid. Den Haag: Ruimtelijk Planbureau.

Renes, G. (April 28, 2008). Personal communication

Rouwendal, J., van Ommeren, J., \& Vermeulen, W. (2004). The development of Dutch housing prices, 1985-1998. Unpublished manuscript.

Ruimtelijk Planbureau (RPB). (2008). The land market for housing: Concerns and strategies of landowners. The Hague: Ruimtelijk Planbureau.

Santen, J. (May 7, 2008). Personal communication

Schuiling, D. (May 19, 2008). Personal communication

Siraa, H. T. (1989). Een miljoen nieuwe woningen: De rol van de rijksoverheid bij wederopbouw, volkshuisvesting, bouwnijverheid en ruimtelijk ordening (19401963). The Hague: SDU Uitgevers.

Siraa, H. T., van der Valk, A. J., \& Wissink, W. L. (1995). Met het oog op de omgevening [with an eye to the environment]. The Hague: SDU Uitgevers.

Taskforce Woningbouwproductie. (2002). Achterblijven woningbouwproductie: Problematiek en maatregelen. Den Haag: Taskforce Woningbouwproductie. 
van der Burg, A. (February 28, 2008). Personal communication

van der Post, W. (April 23, 2008). Personal communication

van der Valk, A. (2002). The Dutch planning experience. Landscape and Urban Planning, 58, 201.

van Zanen, K. (March 11, 2008). Personal communication

Vermeulen, W. (June 26, 2008). Personal communication

Vermeulen, W., \& Rouwendal, J. (2007). Housing supply in the Netherlands. The Hague: Centraal Planbureau (CPB).

Weitz, J. (1999). From quiet revolution to smart growth: State growth management programs, 1960 to 1999. Journal of Planning Literature, 14(2), 266.

Yin, R. K. (2003). Case study research: Design and methods. Thousand Oaks, CA: Sage Publications.

Zonneveld, W. (2007). A sea of houses: Preserving open space in an urbanised country. Journal of Environmental Planning and Management, 50(5), 657. 
APPENDIX A: BENGSTON, ET AL (2004) GROWTH

\section{MANAGEMENT TYPOLOGY}

Public policies for managing urban growth and protecting open space

Policies for managing urban growth

Public acquisition

Fee simple public ownership of parks, recreation areas, forests, wildlife refuges, wilderness areas,

environmentally sensitive areas, greenways, etc. (local, regional, state, national)

\section{Regulation}

Development moratoria, interim development regulations (local)

Rate of growth controls, growth-phasing regulations (local)

Adequate public facility ordinances (local, state)

Upzoning or small-lot zoning, minimum density zoning (local)

Greenbelts (local, regional)

Urban growth boundaries (local, regional, state)

Urban service boundaries (local, regional)

Planning mandates (regional, state)

\section{Incentives}

Development impact fees (local)

Development impact taxes, real estate transfer taxes (local)

Infill and redevelopment incentives (local, state)

Split-rate property tax (local)

Brownfields redevelopment (local, state, national)

Location efficient mortgages (local)

Historic rehabilitation tax credits (state, national)

Policies for protecting open space

Public acquisition

Fee simple public ownership of parks, recreation areas, forests, wildlife refuges, wilderness areas, environmentally sensitive areas, greenways, etc. (local, regional, state, national)

Regulation

Subdivision exactions (local)

Cluster zoning (local, regional)-incentives also sometimes used

Downzoning or large-lot zoning (local)

Exclusive agricultural or forestry zoning (local, state)

Mitigation ordinances and banking (local, state)

Nontransitional zoning (local)

Concentrating rural development (local)

Incentives

Right-to-farm laws (local, state)

Agricultural districts (local, regional, state)

Transfer of development rights (local, regional)

Purchase of development rights, conservation easements (local, state, federal)

Use-value tax assessment (state, national)

Circuit breaker tax relief credits (state)

Capital gains tax on land sales (state) 


\section{APPENDIX B: BASIC TOPOGRAPHY AND LAND USE OF}

\section{THE NETHERLANDS}

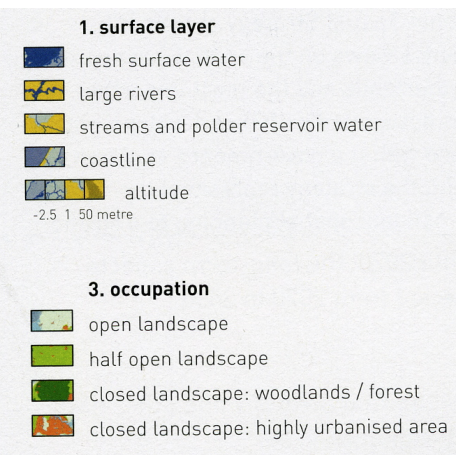

Comparing the two maps, note the highly urbanized area stretched along the country's west coast, where most land lies below sea level.

Source: Ministry of Housing, Spatial Planning and the Environment, pp 67 (2006).

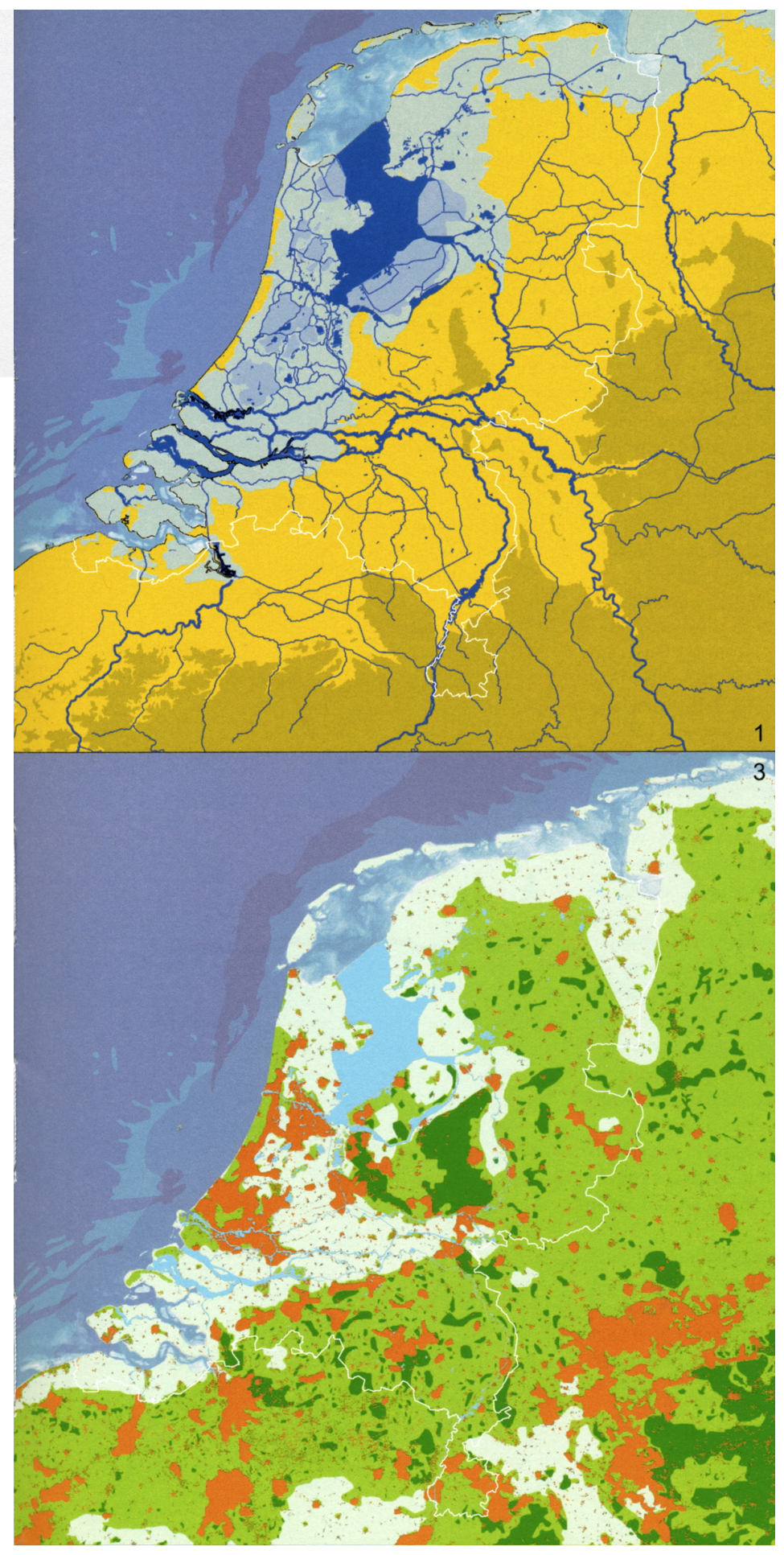




\section{APPENDIX C: EXAMPLE INTERVIEW SCRIPT}

Subject: Koos van Zanen, Housing Specialist - Dienst Ruimtelijke Ordening (Department of Spatial Planning), Municipality of Amsterdam

\section{Getting Started}

\section{- THANK YOU}

- Cover letter

- OK to record?

○ On/off record issues

- How much time?

- In Dutch, is it "day-er-oh"?

\section{Background and Position at DRO}

- Tell me a bit about your training and career path?

- Tell me a bit about your work at the DRO?

- Aside from your (department/position) within the DRO, is there a separate housing agency at the municipality?

- If Yes: How closely do you work with that department?

- If No: Do you do a lot of work directly with private developers and social housing corporations?

\section{Background on my research...}

- Share 2040 GC Map

- Portland, Oregon uses an Urban Growth Boundary to contain low-density sprawl

- Portland also has a tradition of strong, pro-active planning on a regional scale

- There are concerns in the region about the containment of land supply and the effects on housing costs

- At the same time: opportunities to counteract land market inflation via the planning system

- MY INTEREST: Plans/policies/practices utilized in Amsterdam to maintain adequate housing supply and access to affordable housing...within a context of concentrated development

\section{Regulatory Issues}

I'd like to start by asking you about the tools used to contain and concentrate development in Amsterdam.

- I'm familiar with national policies regarding the designation of red and green contours.

- Can you tell me about the process of determining red and green contours in Amsterdam?

- Which levels of government are directly involved?

- Are there competing interests in the process? 
- How often are contour plans revised?

- Is it fair to say that red/green contours have a significant containment effect on the supply of land available for development?

- Are there other important planning tools utilized to contain the supply of land available for development?

$\circ$ Green heart policies?

- Ecological main zones?

O Other?

- When those tools are taken together, do you see the supply of land available for development as relatively fixed... or is it in flux?

\section{Monitoring Issues}

I'm interested in the ways that land markets might be monitored.

- Are there systems in place to monitor the supply of land available for development?

$\circ$ Is that information stored in a database?

- How current is the data?

- How is it maintained/updated?

- Can you tell me about the reasons for (not) monitoring land supply?

- Can you give me some specific examples of how that data is put to use?

I'm also interested in the ways that housing markets might be monitored.

- Is the cost of housing, or access to housing, something that the DRO monitors?

- Is that information stored in a database?

- How current is the data?

- How is it maintained/updated?

- Can you tell me about the reasons for (not) monitoring housing costs?

- Can you give me some specific examples of how that data is put to use?

\section{Planning Action}

- Is the affordability of housing an issue that falls under DRO's area of responsibility?

- If so: what parts of the department are tasked with housing affordability issues?

- If not: does DRO have any responsibility for this issue?

- Could you tell me about the work done within DRO to affect affordability?

○ What are the most important planning tools used to affect affordability?

- Direct or indirect approach?

- Regulatory?

- Incentive-based?

- Direct subsidies?

- Advisory?

- Capacity building?

- Are there important partner organizations/departments in the DRO's work on affordability issues? 
I'd like to ask about a specific aspect of planning that is particularly important in the US context, and that is the density of new housing development.

- Is there much variation in housing density levels in Amsterdam...or is the market fairly uniform in that respect?

- Is housing density an issue that the DRO seeks to influence?

o If not: why not?

- Is this left up to markets?

- Or to another public agency?

- If so: what tools/approaches are used to influence density?

- Regulatory?

- Incentive-based?

- Direct subsidies?

- Advisory?

- Capacity building?

In the Portland context, increasing housing density is seen as an important way to offset increased land prices due to supply regulations.

- Are density issues seen in the same way in Amsterdam, or at the DRO?

- If not: why not?

\section{Land Economics}

Finally, I'd like to ask about the broader issues of land economics that have been running throughout this conversation.

In Portland, where we directly regulate the supply of land available for development, it is generally agreed that this action increases the cost of land within the boundary. Now, there is some debate about how that relates to the cost of housing. But there is agreement about increasing the cost of land available for development.

- Is this an issue that is discussed in Amsterdam?

- Would you say that there is general agreement that constraining land supply increases the cost of land?

- If this is debated:

- Could you tell me a bit about the different positions in that debate?

- Are there specific interest groups associated with either position?

- In planning/policy circles, is there a direct link made between urban containment and housing affordability policies?

- Which parts of the municipal government are responsible for understanding/managing that link?

- What steps are taken if/when land supply is thought to be driving up the cost of housing?

\section{Conclusion}

- Is there anything else you think I might be interested in? 


\section{APPENDIX D: LIST OF INTERVIEW SUBJECTS AND DATES}

\begin{tabular}{|c|c|c|c|c|}
\hline Name & Position Title & Organization (Dutch) & $\begin{array}{l}\text { Organization } \\
\text { (English) }\end{array}$ & Date \\
\hline $\begin{array}{l}\text { Blom, } \\
\text { Floris }\end{array}$ & $\begin{array}{l}\text { Senior Policy } \\
\text { Advisor }\end{array}$ & $\begin{array}{l}\text { Dienst Wonen, } \\
\text { Gemeente Amsterdam }\end{array}$ & $\begin{array}{l}\text { Housing } \\
\text { Department, } \\
\text { Municipality of } \\
\text { Amsterdam }\end{array}$ & $\begin{array}{l}\text { Apr 29, } \\
2008\end{array}$ \\
\hline $\begin{array}{l}\text { Dubbeldam, } \\
\text { Frans }\end{array}$ & $\begin{array}{l}\text { Senior } \\
\text { Planner }\end{array}$ & $\begin{array}{l}\text { Dienst Ruimtelijke } \\
\text { Ordening, Gemeente } \\
\text { Amsterdam }\end{array}$ & $\begin{array}{l}\text { Spatial Planning } \\
\text { Department, } \\
\text { Municipality of } \\
\text { Amsterdam }\end{array}$ & $\begin{array}{l}\text { Jun } 16, \\
2008\end{array}$ \\
\hline $\begin{array}{l}\text { Georgius, } \\
\text { Maarten }\end{array}$ & $\begin{array}{l}\text { Project } \\
\text { Manager }\end{array}$ & AEDES & $\begin{array}{l}\text { Association of } \\
\text { Housing } \\
\text { Corporations }\end{array}$ & $\begin{array}{l}\text { Mar 4, } \\
2008\end{array}$ \\
\hline $\begin{array}{l}\text { Haaker, } \\
\text { Anja }\end{array}$ & $\begin{array}{l}\text { Financial } \\
\text { Specialist }\end{array}$ & $\begin{array}{l}\text { Ontwikkelingsbedrijf, } \\
\text { Gemeente Amsterdam }\end{array}$ & $\begin{array}{l}\text { Land Development } \\
\text { Department, } \\
\text { Municipality of } \\
\text { Amsterdam }\end{array}$ & $\begin{array}{l}\text { May } \\
28 \\
2008\end{array}$ \\
\hline $\begin{array}{l}\text { Klopper, } \\
\text { Nils }\end{array}$ & $\begin{array}{l}\text { Policy } \\
\text { Analyst }\end{array}$ & $\begin{array}{l}\text { Provincie Noord- } \\
\text { Holland }\end{array}$ & $\begin{array}{l}\text { Province of North } \\
\text { Holland }\end{array}$ & $\begin{array}{l}\text { May } \\
27, \\
2008 \\
\end{array}$ \\
\hline $\begin{array}{l}\text { Korthals } \\
\text { Altes, } \\
\text { Willem K. }\end{array}$ & $\begin{array}{l}\text { Professor, } \\
\text { Geo- } \\
\text { Information } \\
\text { and Land } \\
\text { Development }\end{array}$ & $\begin{array}{l}\text { Technische } \\
\text { Universiteit Delft }\end{array}$ & $\begin{array}{l}\text { Delft University of } \\
\text { Technology }\end{array}$ & $\begin{array}{l}\text { Apr 15, } \\
2008\end{array}$ \\
\hline $\begin{array}{l}\text { Maljers, } \\
\text { Frank }\end{array}$ & $\begin{array}{l}\text { Financial } \\
\text { Specialist }\end{array}$ & $\begin{array}{l}\text { Ontwikkelingsbedrijf, } \\
\text { Gemeente Amsterdam }\end{array}$ & $\begin{array}{l}\text { Land Development } \\
\text { Department, } \\
\text { Municipality of } \\
\text { Amsterdam }\end{array}$ & $\begin{array}{l}\text { May } \\
28 \\
2008\end{array}$ \\
\hline $\begin{array}{l}\text { Needham, } \\
\text { Barrie }\end{array}$ & $\begin{array}{l}\text { Professor of } \\
\text { Spatial } \\
\text { Planning }\end{array}$ & $\begin{array}{l}\text { Radboud Universiteit } \\
\text { Nijmegen }\end{array}$ & $\begin{array}{l}\text { University of } \\
\text { Nijmegen }\end{array}$ & $\begin{array}{l}\text { Mar 13, } \\
\text { 2008; } \\
\text { Jun 11, } \\
2008\end{array}$ \\
\hline $\begin{array}{l}\text { Nip, } \\
\text { Maarten }\end{array}$ & $\begin{array}{l}\text { Regional } \\
\text { Planner }\end{array}$ & Stadsregio Amsterdam & $\begin{array}{l}\text { City Region of } \\
\text { Amsterdam }\end{array}$ & $\begin{array}{l}\text { May } \\
21 \\
2008 \\
\end{array}$ \\
\hline $\begin{array}{l}\text { Ploeger, } \\
\text { Ralph }\end{array}$ & $\begin{array}{l}\text { Senior } \\
\text { Housing } \\
\text { Advisor }\end{array}$ & $\begin{array}{l}\text { Ontwikkelingsbedrijf, } \\
\text { Gemeente Amsterdam }\end{array}$ & $\begin{array}{l}\text { Land Development } \\
\text { Department, } \\
\text { Municipality of } \\
\text { Amsterdam }\end{array}$ & $\begin{array}{l}\text { Apr 22, } \\
2008\end{array}$ \\
\hline $\begin{array}{l}\text { Renes, } \\
\text { Gusta }\end{array}$ & $\begin{array}{l}\text { Senior } \\
\text { Researcher }\end{array}$ & $\begin{array}{l}\text { Ruimtelijk Planbureau } \\
\text { (RPB) }\end{array}$ & $\begin{array}{l}\text { Netherlands Bureau } \\
\text { of Spatial Planning }\end{array}$ & $\begin{array}{l}\text { Apr 28, } \\
2008\end{array}$ \\
\hline
\end{tabular}




\begin{tabular}{|c|c|c|c|c|}
\hline $\begin{array}{l}\text { Santen, } \\
\text { Joline }\end{array}$ & $\begin{array}{l}\text { Policy } \\
\text { Advisor }\end{array}$ & $\begin{array}{l}\text { Provincie Noord- } \\
\text { Holland }\end{array}$ & $\begin{array}{l}\text { Province of North } \\
\text { Holland }\end{array}$ & $\begin{array}{l}\text { May 7, } \\
2008\end{array}$ \\
\hline $\begin{array}{l}\text { Schuiling, } \\
\text { Dick }\end{array}$ & $\begin{array}{l}\text { Professor of } \\
\text { Spatial } \\
\text { Planning and } \\
\text { Housing } \\
\text { Policy }\end{array}$ & $\begin{array}{l}\text { Universiteit van } \\
\text { Amsterdam }\end{array}$ & $\begin{array}{l}\text { University of } \\
\text { Amsterdam }\end{array}$ & $\begin{array}{l}\text { May } \\
19 \\
2008\end{array}$ \\
\hline $\begin{array}{l}\text { van der } \\
\text { Burg, Arjen }\end{array}$ & $\begin{array}{l}\text { Senior } \\
\text { Strategy } \\
\text { Expert }\end{array}$ & $\begin{array}{l}\text { Ministerie van } \\
\text { Volkshuisvesting, } \\
\text { Ruimtelijke Ordening } \\
\text { en Milieu (VROM) }\end{array}$ & $\begin{array}{l}\text { Ministry of } \\
\text { Housing, Spatial } \\
\text { Planning and the } \\
\text { Environment }\end{array}$ & $\begin{array}{l}\text { Feb 28, } \\
2008\end{array}$ \\
\hline $\begin{array}{l}\text { van der } \\
\text { Post, } \\
\text { Willem }\end{array}$ & $\begin{array}{l}\text { Guest } \\
\text { Lecturer; PhD } \\
\text { Candidate }\end{array}$ & $\begin{array}{l}\text { Universiteit van } \\
\text { Amsterdam; } \\
\text { Amsterdam School of } \\
\text { Real Estate }\end{array}$ & $\begin{array}{l}\text { University of } \\
\text { Amsterdam; } \\
\text { Amsterdam School } \\
\text { of Real Estate }\end{array}$ & $\begin{array}{l}\text { Apr 23, } \\
2008\end{array}$ \\
\hline $\begin{array}{l}\text { van der } \\
\text { Valk, } \\
\text { Arnold } \\
\end{array}$ & $\begin{array}{l}\text { Professor of } \\
\text { Land Use } \\
\text { Planning }\end{array}$ & $\begin{array}{l}\text { Wageningen } \\
\text { University }\end{array}$ & $\begin{array}{l}\text { Wageningen } \\
\text { University }\end{array}$ & $\begin{array}{l}\text { Jun } 5 \text {, } \\
2008\end{array}$ \\
\hline $\begin{array}{l}\text { van Dijk, } \\
\text { Terry }\end{array}$ & $\begin{array}{l}\text { Assistant } \\
\text { Professor of } \\
\text { Land Use } \\
\text { Planning }\end{array}$ & $\begin{array}{l}\text { Universiteit van } \\
\text { Groningen }\end{array}$ & $\begin{array}{l}\text { University of } \\
\text { Groningen }\end{array}$ & $\begin{array}{l}\text { Jun } 17, \\
2008\end{array}$ \\
\hline $\begin{array}{l}\text { van Zanen, } \\
\text { Koos }\end{array}$ & $\begin{array}{l}\text { Senior } \\
\text { Planner }\end{array}$ & $\begin{array}{l}\text { Dienst Ruimtelijke } \\
\text { Ordening, Gemeente } \\
\text { Amsterdam }\end{array}$ & $\begin{array}{l}\text { Spatial Planning } \\
\text { Department, } \\
\text { Municipality of } \\
\text { Amsterdam }\end{array}$ & $\begin{array}{l}\text { Mar 11, } \\
2008\end{array}$ \\
\hline $\begin{array}{l}\text { Vermeulen, } \\
\text { Wouter }\end{array}$ & Researcher & $\begin{array}{l}\text { Centraal Planbureau; } \\
\text { Vrije Universiteit }\end{array}$ & $\begin{array}{l}\text { Netherlands Bureau } \\
\text { for Economic } \\
\text { Policy Analysis; } \\
\text { Free University }\end{array}$ & $\begin{array}{l}\text { Jun } 26, \\
2008\end{array}$ \\
\hline
\end{tabular}




\section{APPENDIX E: MAP OF THE RANDSTAD}

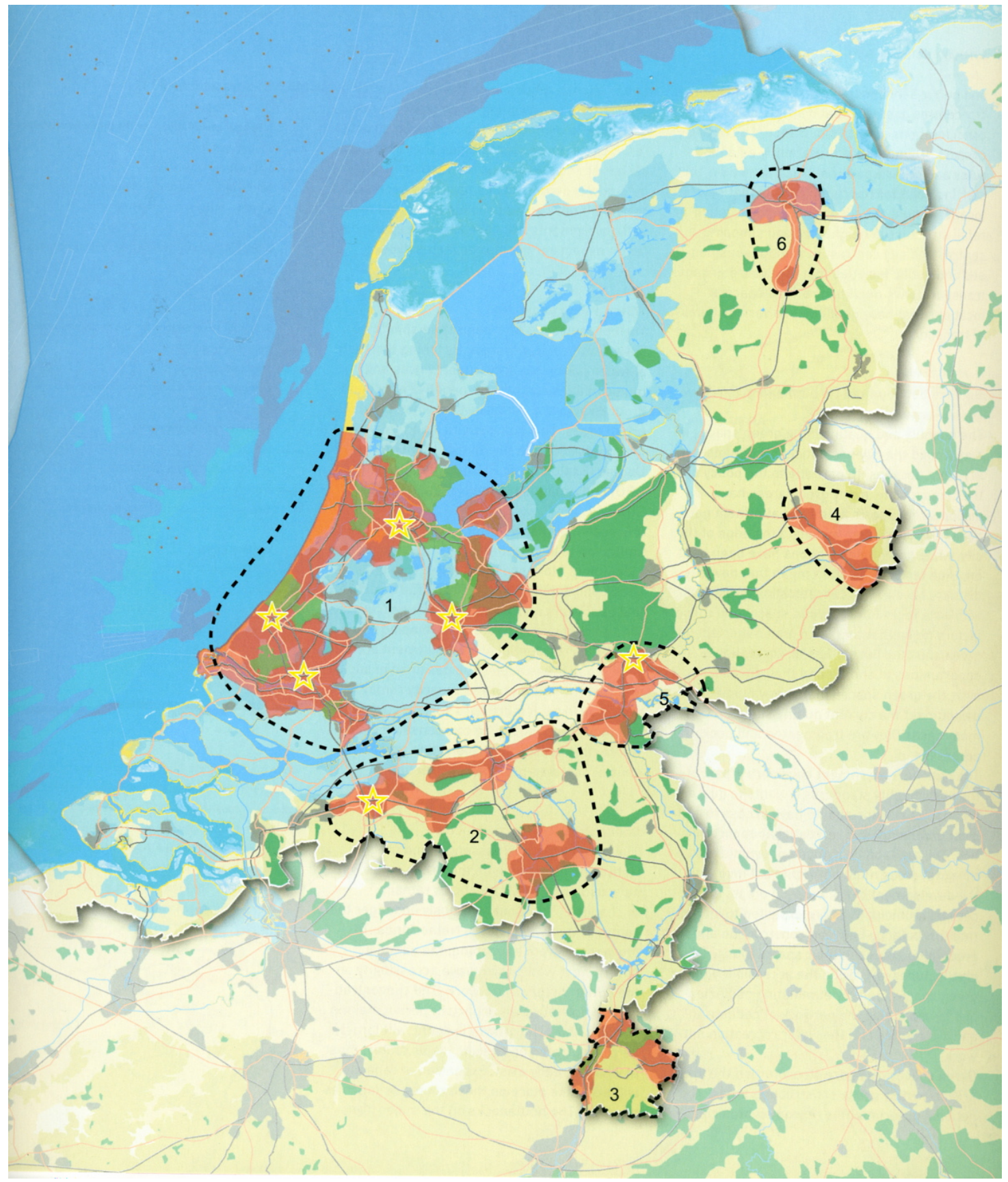

The Randstad conurbation (Area 1, above) includes the cities of Amsterdam, Rotterdam, the Hague, and Utrecht. In total, the Randstad is home to 7.5 million of the nation's 16.5 million people. Source: Ministry of Housing, Spatial Planning and the Environment, pp 19 (2006). 